\title{
Narratividad y poeticidad en la composición del poema de Cesare Pavese
}

\author{
JAVIER DEL PRADO BIEZMA \\ Universidad Complutense de Madrid \\ jmbiezma@yahoo.es
}

\begin{abstract}
Resumen
El presente ensayo tiene dos objetivos; uno general, el estudio de las marcas de la poeticidad post-simbolistas, y otro particular, ver cómo se sitúa el intento poético de Pavese ante la dificultad de hacer poesía, evitando la herencia simbolista, sin caer en una poesía simplemente narrativa. Pavese construye un poema que, compuesto por materiales que proceden del mundo narrativo, se instala en la casi inmovilidad, mediante una especie de fijación fotográfica, una especie de presente atemporal. El poema pavesiano sería así, a la narración pura lo que la fotografía es a la película cinematográfica. El autor consigue de este modo una especie de poesía 'pura', liberada tanto de narratividad como de argumentación discursiva.
\end{abstract}

Palabras clave: Pavese, poeticidad, atemporalidad, poema, fotografía verbal.

Narrativity and poetry in the composition of Cesare Pavese's poem

\begin{abstract}
This essay has two goals: a general one, the study of post-symbolist poetical traces and a particular one, the place of the poetical attempt of Pavese to overcome the difficulty of writing poetry, avoiding the Symbolist inherintance and escaping a simple narrative poetry. Pavese builds a poem set up in the quasi inmovility, composed by elements coming from the narrative world, using a sort of photographic fixation, a a-temporal present. The pavesian poem would be in reference to the pure narrative what the photography is to the motion picture. The author reach in this way a kind of 'pure' poetry, free both from narrativity and discursive argumentation.
\end{abstract}

Key words: Pavese, poetry, atemporality, poem, verbal photography.

Sumario: Preliminares 1. Narratividad y poeticidad en Lavorare stanca. 1.1. De la narración a la descripción (la anécdota cuajada en el cuadro) 1.1.1. Paesaggio II 1.1.2. Lavorare stanca 1. 2. La deconstrucción de la descripción (redundancias, traspasos y corrimientos semánticos) 1 . 2.1. Il carrettiere y La voce 1. 2. 1.1. Desplazamientos metasémicos fundados en la analogía 1.2.1.2. Procedimientos morfosintácticos ligados a la repetición 1.2.2. A modo de epílogo: la modulación semántica y el poema musical. 2. Siempre queda la duda. Bibliografía.

Prado Biezma, Javier del. Narratividad y poeticidad en la composición del poema de Cesare Pavese. Cuadernos de Filología Italiana, nº extraordinario: págs. 307-338. 


\section{Preliminares}

Antes de entrar directamente en el tema, permitidme una pequeña advertencia: he incluido en mi título la palabra poema, aunque esta palabra no vaya a aparecer mucho a lo largo de mi intervención. La he puesto porque creo que el gran problema de la poesía, en cuanto a la necesidad (o no) de adjudicarle una identidad genérica, no es, contrariamente a lo que se piensa, su participación o pertenencia a ese espacio enunciativo que se construye en un uso especial del lenguaje y al que llamamos poeticidad, junto al de narratividad y discursividad, sino su modo de organizarse como artefacto literario autónomo, con el fin de dar cuerpo, claro y distinto, a esa poeticidad; es decir su modo de organizarse en poema - en una manifestación formal a la que llamamos poema- sin saber muy bien qué queremos expresar al nombrarlo de este modo. Quiero con ello decir que, si bien sigue existiendo un problema de lengua ligado a la noción de poeticidad ( $\mathrm{y}$ he intentado aprehenderlo en dos ocasiones ${ }^{1}$ ), el problema de esta es mucho mayor, cuando se enfoca el campo literario en función de una teoría de los géneros y de los subgéneros y no solo en función de una de las instancias primarias del lenguaje ${ }^{2}$.

Resumiré el problema de manera expeditiva con esta doble pregunta: ¿qué es, en sí, y cómo se organiza para conseguir ese en sí, un texto llamado poema? Y dejo de lado, evidentemente, la respuesta o solución que nos podría venir del lado de la métrica, capaz de organizar un todo, más o menos extenso, cerrado musicalmente ( $\mathrm{y}$ temáticamente) sobre sí mismo, pues es evidente que, desde Baudelaire (y antes), con la invención del poema en prosa no podemos identificar poema y verso ni oponer poesía y prosa; tampoco podemos basarnos en las soluciones propuestas por Mallarmé (por muy sugerentes que sean), en la fusión de música y de poesía y de poesía y trabajo de estilo, son harto confusas y contradictorias, si las confrontamos a su teoría del verso - tanto en las formas heredadas de este como en las formas autogestionadas ${ }^{3}$.

Voy a intentar acercarme, pues, a la raíz de la obra poética de Pavese, pues pienso que para él, también, el problema de lo que podemos llamar su aventura poética nace de esta doble incógnita, de no fácil solución.

Cuando, con vistas a este Congreso, empecé a subrayar y a hacer fichas por las poesías, Le poesie de Pavese (y mi edición es la de Mariarosa Masoero) (Pavese

${ }^{1}$ Una de manera global, en Prado (1993), partiendo de una tesis que podríamos calificar de antijakobsoniana, (afirmando, por un lado, la referencialidad de la función poética y defendiendo, por otro, la dinamicidad sintagmática del poema, afianzada en la progresión de su organización semántica); la otra, más puntual, más técnica, con el fin de qué manera la modalización enfática (prosódica o semántica) del lenguaje es la base textual elegida por la poeticidad para 'encarnarse' en lengua, Del Prado (2005).

${ }^{2}$ Para ver como defino la noción de instancias primarias del lenguaje (narratividad, poeticidad y discursividad), desde una perspectiva epistemológica, a no confundir con la noción de funciones del lenguaje, remito a Del Prado (1996).

${ }^{3}$ Releer La musique et les lettres, (Enquête de Jules Huret Sur l'Évolution littéraire y el enigmático último párrafo de Préface para Un coup de dés jamais n'abolira le hasard. 
1998), me vinieron a la mente, como a galope, dos aspectos de gran interés para mí: uno temático y otro estrictamente formal.

El temático se centraba en la riqueza sensorial (visual, táctil, gustativa, olfativa $\mathrm{y}$, en menor medida, auditiva) que se desplegaba a raudales de viento, agua y savia por la poesía de un autor que hacía pasar y volver a pasar, de poema en poema, a sus personajes por un marco geográfico que había sido el mío, durante casi toda la adolescencia, aunque yo miraba más del lado de la Dora Riparia que del Pò - y ello, a pesar de comprobar, en la abundante bibliografía crítica sobre el autor, cómo los estudiosos ya habían tratado ese mundo de horizontes, de colinas, de bosque, de viñas y de ríos. Pensaba yo que podía haber ido más lejos que alguno de ellos en la aprehensión de ese paisaje, aunque realista alucinado, sin tener que dar el salto del naturalismo alla realtà simbolica ${ }^{4}$, rastreando, por ejemplo, el campo semántico del olfato, puesto que muchos personajes se pasan grandes momentos de su vida «annusando nell'aria» $(22)^{5}$, como animales primarios, una humedad terrosa, un perfume de lluvia o de niebla o un vestigio de donna. «Acerca de verbo annusare y de sus variaciones analógicas en la obra de Pavese» hubiera sido, a este respecto, un título muy bonito - y muy pertinente.

El aspecto formal era, a primera vista, de una simpleza absoluta, si pensamos en los escasos intereses musicales de la poesía (y de su crítica) en nuestros días. Se trataba (y se trata, pues no he descartado volver sobre el tema algún día, cuando haya aprendido algo más sobre el tema) del problema de la versificación en Pavese y, por consiguiente, del abandono o de la permanencia del joven poeta en el interior de una concepción musical, tradicional, del verso. Un gran problema para el joven Pavese; un problema que le obsesiona (al menos en apariencia) a lo largo de toda su producción poética y, como ayer se decía, incluso prosística.

Me interesaba este tema, pues, frente al aparente predominio del verso libre en la poesía del s. XX y lo que va del s. XXI, Pavese, obedeciendo, tal vez sin saberlo, al último Mallarmé, pasada ya la sorpresa ambiental y necesaria del verso libre, hace un esfuerzo meditado, concienzudo, para crearse una nueva métrica, apta para cantar su yo y el mundo que lo rodea - una métrica musicalmente adaptable a su espíritu falsamente narrativo, pero fiel (aunque no esclava) a unos patrones preestablecidos. No está solo en el empeño; y observo que en muchos de los poetas españoles e italianos que conozco encontramos la misma realidad o el mismo procedimiento en cuanto a la organización musical del verso: lo que he llamado (Prado 2006) «las matrices prosódicas del endecasílabo» (módulos combinados de 7, 5 o 4

\footnotetext{
4 Término tan ambiguo (en el interior de una hermenéutica con pretensiones de seriedad) pero tan ajustado a lo que Pavese pretende aprehender con su poesía (y en parte con su prosa). Mi trabajo, por otro camino, acabará fijándose en él.

5 Todas las cifras entre paréntesis remiten a la edición antes referida.

${ }^{6}$ «Une heureuse trouvaille avec quoi paraît à peu près close la recherche d'hier, aura été le vers libre. modulation (di-je souvent) individuelle, parce que toute âme est un nœuds rythmique» (La musique et les lettres).
} 
-según las sinalefas- y de 9 sílabas) o su duplicado (el verso de 14 o 13 sílabas, según las sinalefas, de nuevo) siguen constituyendo la base de un verso (llamado) libre; lo que nos lleva a pensar que la versificación no es un simple problema artificial de preceptiva ocasional, sino algo inherente a la prosodia de una lengua; estando, por razones de la variedad en la acentuación de las palabras, la italiana y la española muy hermanadas a este respecto ${ }^{7}$. Por ello, me llamaba la atención cómo en muchos poemas de Pavese, sobre todo en aquellos cuyos versos están construidos siguiendo la conjunción métrica de 7+6 (los más habituales), pero también aquellos construidos en la conjunción de 7+10 (muy abundantes, también), el ritmo que el poeta consigue, al juntar y contraponer un elemento impar a uno par, es un ritmo muy parecido al del alejandrino francés (de trece sílabas si contamos los pies a la española o a la italiana), sobre todo el primero patrón, lento y acompasado (anapéstico, dicen algunos), aunque también el segundo. Y, leyendo y releyendo a Pavese, me venían a la punta de los dedos los alejandrinos narrativos de V. Hugo.

Sin embargo, me llamaba también la atención que el patrón medieval de un heptasílabo duplicado, $7+7$ ( $\tan$ común en la poesía española, cuando todos los modernistas quieren huir, ellos también, del endecasílabo) fuera a su vez muy frecuente en Pavese, con su capacidad para anular (no sé si es la palabra exacta) la impronta impar del heptasílabo, Tanto el primer patrón como el segundo y el tercero le dan al verso de Pavese un tamaño (las righe lunghe, de las que habla el poeta en Il mestiere di poeta), una lentitud y un acompasamiento que podemos considerar épicos o narrativos (o narrativos por épicos).

Esta aparente contradicción (lo español e italiano impar, confrontado y equiparado en sus efectos a lo francés), además de llenarme de sorpresa, agudizaron mi interés francesista e hispanista por el tema. Ahora, a posteriori, veo que este tema podría ser utilizado, también, para explicar el binomio conflictivo de la propuesta poética pavesiana: la creación de el poema-racconto - con lo cual este problema de métrica tendría un alcance conceptual más alto y complejo que lo que da a entender cuando el poeta cuando califica la música de su verso de un simple mugolare (Pavese 1998: 110$)^{8}$.

${ }^{7}$ Lo que permite el triunfo definitivo del endecasílabo en la España renacentista, convirtiéndose en el verso español por excelencia (lógico, pues no podemos olvidar que la canción española tradicional juega muy frecuentemente con la alternancia del heptasílabo y del pentasílabo), mientras que en Francia, tras el primer impulso (L'Olive de Du Belley y Amours de Cassandre de Ronsard), la versión francesa del endecasílabo desaparece, imponiéndose para siempre (y tiránicamente) un verso de ritmo par: el alejandrino de 12 sílabas - doblemente par, pues dividido tradicionalmente en dos hemistiquios nos sigue dando dos versos pares, de seis sílabas. Ello explica los esfuerzos de la métrica francesa para, sin abandonar el alejandrino, conquistar un ritmo impar, ternario, que se resiste a la prosodia francesa: ello se conseguirá con la división, a su vez, del hexámetro en dos hemistiquios, con lo que se consigue un verso estructurado de esta manera $(3+3+3+3)-$ anapéstico, de nuevo) o, con la división más moderna, tan querida por V. Hugo, del verso de doce sílabas en tres partes $(4+4+4)$. Ahora bien, se mire por donde se mire, siempre volvemos a encontrar un ritmo regular, acompasado y, en cierto modo, monótono, ajeno a la versatilidad que propicia la división de un verso impar, que siempre dará un módulo impar más otro par.

${ }^{8} \mathrm{Y}$, si le hacemos caso, tendríamos que calificar su elaboración semántica del poema de un simple ruminare, por las razones que luego veremos. 
Estaba en estas, cuando me puse a releer en paralelo Lavorare stanca e Il mestiere di poeta (ya tratado por mí (Prado 2006), para dilucidar la dialéctica entre inspiración y trabajo poéticos, muy en la estela mallarmeana). Tras su lectura, me di cuenta de que esta comunicación era la ocasión esperada desde hacía tiempo para enfrentarme de veras con la obra poética de Pavese, no como crítico o erudito pavesiano, que no soy (¡dios me libre de la gracia de la erudición!), sino como lector que intenta comprender y dar sentido a un esfuerzo que el autor vive como un compromiso epistemológico y como una aventura estética; debía hacerlo, fuera cual fuera el resultado, de cara a este momento que me sitúa ante la escritura.

Desde el primer instante, se me presentaron como elementos esenciales de este enfrentamiento dos aspectos que se van a convertir en los dos ejes de mi análisis:

a. La demostración fehaciente del ajuste intelectual entre la composición de Lavorare stanca y la teorización llevada a cabo a posteriori por Pavese, en los tres textos metadiscursivos en prosa, en los que habla directamente de este libro; demostrando, una vez más, la falacia (dogma de fe en ciertos ambientes poetiles) de la oposición entre teoría y praxis en la experiencia de los grandes creadores; mostrándose, a su vez, como más veleidosa, aunque hipercrítica, la reflexión llevada a cabo sobre las poesías non ancora scritte - lo que, de paso, me demostraba que la praxis y la teorización forman un todo y que teoría (previa) sin praxis nos ofrece edificios endebles y virtuales. De hecho, y a mi entender, sin ser inútil, esta segunda parte del $\mathrm{Me}$ stiere di poeta sirve para muy poco, cuando se trata de enfrentarse a la auténtica aventura poética de Pavese, centrada en los problemas que plantea Lavorare stanca ${ }^{9}$.

b. Como esto no me era suficiente, llevado por la ambición del ignorante (y del viejo hiperactivo), se me ocurrió que debería trazar, construir, en explicación textual (en ningún caso erudita e histórica), el límite, la frontera entre la aventura que se inicia en I Mari del Sud y el resto de la obra (tanto anterior como posterior a Lavorare stanca). Desde mi pobre saber italiano (asumiendo que existe un antes y un después de I mari), esa frontera no me parecía del todo clara, sobre todo la que separa Lavora stanca de la producción anterior; creyendo que podía resolver, yo, Il Problema dell'unità poetica in Pavese ${ }^{10}$ - y ya me había fijado en algún que otro poema para demostrarlo; entre otros, Frasi all'innamorata (del 4 al 10 de agosto de 1930), el último poema escrito antes de Lavorare stanca y de Attorno a Lavorare stanca; estos poemas ponían de manifiesto que Estravaganti scelte lo era (extravagante) por algún motivo más hondo que aquellos (ocasionales) confesados por el poeta en el Mestiere.

Esta comprobación, como la de ciertas pervivencias estructurales en los poemas (de las temáticas, ligadas al universo imaginario, no hablo, pues guardan una coherencia total a lo largo de toda la obra poética, incluso si bajamos a los niveles de la vivencia decadentista del cosmos y del yo ${ }^{11}$, propia de los primeros poemas, pero

${ }^{9}$ Lo que no es obstáculo para que algunos puedan preferir poemitas (más simples, más sensibles, de mayor levedad e impronta (y no quiero emplear la palabra postmoderna,; como los que encontramos en Verrà la morte...

${ }^{10}$ Me permito robarle el título al artículo de Dolce (1969).

11 «L'acqua / è la stessa nel buio degli anni morti», «Ogni viso contiene / come un frutto maturo un sapore andato» (Paesaggio VIII, Pavese 1998: 95). De hecho todo este poema, como La notte, ambos pertenecientes a Lavorare, son plenamente decadentistas. 
que perviven incluso en Lavorare stanca) de la producción posterior, incluso en Verrà la morte, me permitirían demostrar, pensaba, que, más que un corte preciso, que un ejercicio volitivo, revolucionario, lo que existe en esta aventura poética es una evolución por etapas más o menos estancas, con fronteras más o menos porosas; una evolución del adolescente prematuramente maduro que intenta huir de los modelos dominantes (petraquismo y dantismo, aún, Leopardi y toda le herencia simbolista - la francesa y la italiana, siempre), buscando un espacio nuevo, adecuado a su propia organización mental: ideológica - no lo olvidemos - en el socialismo, perceptiva, en la impregnación del microcosmos piamontés, imaginaria, en la herencia de un país poblado y nombrado a través de los dioses, aunque ya no existan ${ }^{12}$, existencial, en una carencia de tono vital, de cansancio biológico, casi cósmico y estéti$c a$, en la aparente voluntad de centrar la escritura poética en torno a la narratividad, con la persistencia del verso - pero en el rechazo de la métrica tradicional. Una vez encontrado el modelo, Pavese acota un espacio selecto de toda esta producción y lo publica como "perfecta" unidad.

No olvidemos que Pavese es consciente de esta evolución, tal vez menos de lo que dice, cuando alude en Il mestiere di poeta, al problema, aunque de soslayo: «innumerevoli tentativi hanno preceduto I mari del Sud» ${ }^{13}$; no se trata sólo de tentativas, a mi entender; se trata de la existencia de un taller de trabajo poético - y alguna de esas tentativas son ya realizaciones y nada pacate, aunque chiare, como califica al poema que instituye como prototipo de la parte central de su obra ${ }^{14}$.

El poema Frasi all'innamorata me ofrecía:

a. La pervivencia del yo lírico (biográfico o imaginario, muy cercano al romántico, con su capacidad para crear artefactos líricos supuestamente autobiográficos), casi como en cualquier canzoniere tradicional, casi como en sus primeros canzonieri. Digo casi, porque en la primera parte del poema ese yo lírico se disuelve en un yo narrativo y descriptivo que toma posesión de la realidad (espacio y gestos), desde una perspectiva distante, en cierto modo, objetivante, frente a la pujanza emergente del nosotros ${ }^{15}$ y del tú; sólo en la segunda parte, este yo se compromete y asume la relación lírica con el personaje que le acompaña ( $(\mathrm{O}$ mia bella bambina, stasera non sono il compagno») recuperando, en la tercera parte, el distanciamiento narrativo, (descriptivo, más bien), de una manera brutal, incluso: «Ecco il Pò. - Com'è bello!.... Stasera è un cristallo» (Pavese1998: 298), aunque entreverado con elementos propios de la modalización enfática, que provienen del yo lírico romántico.

\footnotetext{
${ }^{12}$ Como ya hemos dicho, en eco invertido, pero muy cercano, de la argumentación de Dialoghi con Leucò.

13 «I mari del Sud che viene dopo questa naturale preparazione, è dunque il mio primo tentativo di poesia-racconto e giustifica questo duplice termine..» Pavese (1998: 108).

14 Ahora, a posteriori, me doy cuenta de que mis análisis inmanentes, sin pretenderlo, no hacen sino justificar la edición de 1943; pero para llegar a ello me era preciso tener delante de los ojos la edición de Masoero.

15 Un nosotros, seguido de un ellos, que será el gran triunfador de Lavorare stanca: «Stamattina non sono più solo. Una donna recente sta distesa sul fondo e mi grava la prua della barca», en Tradimento Pavese (1998: 25), dice la voz lírica, como condensando la experiencia de identidad tribal, anunciada en Antenati.
} 
b. La condensación, en un paisaje de itinerancia, de todo el material naturalista (que Pavese considera naturalista; es decir, no idealizado biográficamente en introspección y/o, librescamente, en símbolo o metáfora)... Todo el paisaje que va a configurar la geografía alucinada, en decorado, personajes y anécdotas, de Lavorare stanca y de su entorno. Paisaje y personajes, veía yo, manipulados por procedimientos poéticos nada naturalistas, pero que ya aparecen en los primeros poemas. Y a este respecto venían a darme la razón bastantes textos de Rinascita y de Le febbri di decadenza. Bastaba, para confirmarlo, con rastrear el tema de la amada (en el paso de la donna -casi dantiana- a la bambina y a la ballerina, recuperando, finalmente, el término de donna, pero ya desacralizado, como sinónimo de mujer, si no de hembra). Bastaba con rastrearlo, desde los primeros poemas de Sfoghi (Beata Beatrix, por ejemplo) ${ }^{16}$ a los poemas «en marcha» ${ }^{17}$, que se inician con «Oh! Chiome d'oro, bella ballerina» al poema que nos ocupa: «Vado a spasso in silenzio con una bambina / abbordata per strada» (Pavese 1998: 297), configurando estas poesías un verdadero poemetto fragmentado y disperso. Bastaba para confirmarlo, también, el rastreo de la aprehensión sensorial del tema de la vegetación (colina o llanura, natural o agrícola - el verdadero marco natural de Lavorare); y me fijo en el bellísimo y temprano poema, «O colli dove nacqui, sempre v'avrò nel cuore», en el que, aún bajo la mirada del yo lírico tradicional, emergen todos los temas agrícolas y paisajísticos de Lavorare: luz, bosques, laderas, hileras de vides, trabajadores artesanos y agrícolas, vendimia, hierba fresca, nubes, etc. etc., sin ningún tipo de mistificación romántica o simbolista.

Del mismo modo, mirando ya hacia fuera, desde la frontera exterior de Lavorare stanca, el libro se concluye con una serie de poemas sobre la alternativa temática del uomo solo / uomo vecchio - Semplicità (1935), L'instinto (1936), Paternità (1935), Lo stedazzu (1936); poemas que se prolongan como un eco natural en Gelosia II (1937), fuera ya de Lavorare..., pero compuesto aún con el mismo patrón temático y métrico de los poemas anteriores. Rompiendo las fronteras del "libro", los cinco poemas componen un auténtico micro-canzoniere naturalista, en el que la unidad de la composición viene dada, apriorísticamente, por el tema (quest'uomo), pero sobre todo por cierta organización del poema, en el que la materia narrativa que les sirve de base entra en dialéctica textual con los elementos primarios de la poeticidad - pero luego volveremos sobre este tema, pues es el tema central de nuestra propuesta.

A lo largo de esta lectura intencionada he ido tomando conciencia (y creo que Pavese estaría de acuerdo conmigo) de que no se puede estudiar Lavorare stanca como una isla, en medio del conjunto de la obra, sino como una scelta privilegiata, con fronteras porosas; scelta en la que, paradójicamente, el poema que menos se

${ }^{16} \mathrm{Y}$ otros: «Ti vidi un giorno per alcuni istanti / e so che mai potrò piú rivederti» $\left(3^{\circ}\right.$, Per un'attrice di cinematografo giovanissima....). (Pavese 1998: 156).

17 Empleo la expresión juanramoniana para designar una persistencia en los temas y en las formas que se van depurando de poema en poema, en un caminar incesante de escritura, hasta llegar (o no llegar) a una meta mental idealizada; idea o práctica que contrasta con la fórmula, también de Juan Ramón Jiménez, «no lo toques ya más, que así es la rosa». 
integra, de cara a la construcción de una unidad (esa unidad de sentido y de forma conseguida a posteriori, conseguida tras la realización de cada singularidad poemática, que tanto cuestiona pero que tanto obsesiona al poeta), es precisamente el poema que sirve de pórtico y de enseña (pero no de patrón, como luego intentaré demostrar) a la obra que viene tras él: I mari del Sud, y ello se debe, justamente, al exceso, en este poema, de narratividad no abolida, no destructurada o, al menos, no compensada con los elementos traídos desde la poeticidad misma. Porque, como muy bien sabe el lector, si el presupuesto teórico de Pavese, al intentar la invención del poema-racconto, es expulsar a la poeticidad que le precede del horizonte de su poema, esta vuelve - y con qué vigor- por las rendijas de la narratividad; - y no solo, como cabría pensar, gracias al imponente (sí) armazón musical de su métrica o a la obsesión por determinados temas cósmicos, tan presentes en su obra, que podrían ser calificados, vulgarmente, de poéticos, sino gracias a los procedimientos que emplea para desbaratar el material narrativo que les sirve de base; material que, sin ese desbataramiento (esa «deconstrucción epistémica», dirían algunos ${ }^{18}$ ), no podría dar acceso, con su nueva organización, a la realidad simbólica, tal como la entiende el poeta ${ }^{19}$ y tal como vamos a intentar definirla.

Esta reflexiones y estas comprobaciones ingenuas me llevaban a una conclusión y a una necesidad de simplificar mis perspectivas, si quería hacer una comunicación sencilla, comprensible y honrada, como era mi obligación hace unos días al exponer estos presupuestos en público (honrada, es decir, en correspondencia con mis conocimientos pavesianos - que no eran muchos).

En primer lugar, aunque sea paradójico, la conclusión.

La experiencia poética de Pavese, en su dialéctica entre praxis y teoría, en su voluntad por definir y fijar con tanto titubeo y tanta dificultad el espacio propio de su poesía, me ponía de manifiesto varios aspectos que voy a intentar exponer de la manera más clara posible.

Pero antes quiero hacer referencia al tema de la dificultad y del esfuerzo que, de nuevo, oponen la práctica de Pavese a uno de los tópicos de la creación poética nacidos tras el Romanticismo. Trabajar el verso, ahondarlo (le creuser), como decía Mallarmé, para encontrar en él la esencia de las cosas, (musical en el francés, casi biológica en Pavese) es algo que cansa, como todo trabajo en el que el espíritu quiere encarnarse en una forma material. Si hay búsqueda necesaria ${ }^{20}$ de materiales («la

18 Pero el concepto de deconstrucción implica un presupuesto ideológico (ontoepistemológico) que no comparto: creo en la capacidad que tiene una persona para organizar una vida en torno a un proyecto (que no es la simple proyección, eyección, de pulsiones, deseos o herencias incontroladas), aunque sea para entregársela a la muerte, y en la capacidad que tiene un escritor para organizar un artefacto de sentido y de expresión (como resultante de ese mismo proyecto - susceptible de aunar, en el trabajo estético, proyecciones y deyecciones), aunque sea para entregárselo al semiólogo que, a pesar de las apariencias, no será capaz de abolir su significado unitario - sólo, de poner de manifiesto ciertas contradicciones (relativas) que su ideología pretenderá elevar a la categoría de absoluto - insignificante, en su significancia.

19 Me interesa recoger aquí la frase de Eliseus Elitis (1988): «Hasta los más crudos realistas, en la más insulsa piedra tocan, sin darse cuenta, un poco de más allá. Una ermita sobre las rocas está 'tan ligada' a ellos que les parece parte de la naturaleza. Y lo es, tan irreal....»

20 «La necessità del mio lavoro» (Pavese 1998: 113). 
realtà fantastica», «l'ansia del problema di come intendere...»), si hay búsqueda de una forma (una métrica adecuada a esta realtà, capaz de soslayar la tradicional heredada, cómoda y musical, pero que no le es propia, apropiada), si hay voluntad de composición («La necessità del mio lavoro»), si hay decisión de abandonar una forma y un contenido cuando estos ya han sido conquistados, dominados, en vez de instalarse en la rutina estética de la técnica adquirida, habrá dificultad («presentimento di questa difficoltà», «una tranquilla occhiata porterà l'ordine e l'unitá nel laborioso caos che domani comincia»; pero habrá, también alegría en la conquista, «la gioia della difficoltà vinta». Y si he vuelto sobre este tema, tan obsesivo en el Mestiere di poeta como en el Mestiere de vivere, es para poner de manifiesto hasta qué punto la escritura de Pavese es un "proceso", una "conquista" existencial, aunque algunos puedan considerar que es un fracaso (y ello - orgullosos sectarios - porque no responde a su idea de la poesía).

Y vuelvo ahora a los aspectos que me ponían de manifiesto dicha dificultad y dicho, en cierto modo, triunfo.

$1^{\circ}$. Es preciso considerar Lavorare stanca como una toma de conciencia de la poeticidad en tanto que práctica epistemológica (en el esfuerzo, en la incertidumbre, en la persistencia, en la conciencia de fracaso) inscrita en el lenguaje poético total ${ }^{21}$, en la que no cabe separar la dimensión práctica de la teórica y cuyo objeto es la aprehensión de la realidad, lejos de cualquier tipo de mistificación con voluntad transcendente (el gran escollo de toda poesía no experimental formalista o política, después de la muerte de Dios); y los poemas son, en este aspecto, como decíamos más arriba, textos muy cercanos de los Dialoghi con Leucò, en su relación de convivencia racional con los dioses que poblaron el mundo mediterráneo; pero lejos, también de cualquier juego estético encerrado en sí mismo.

Una aprehensión de la realidad muy compleja, si la analizamos bien, pues se opone

a. por un lado, al realismo decimonónico, como pretensión de objetividad llamémosla, vulgar o científica; lo que iría en contra, tanto de la necesidad de incorporar, por un lado, «una espressione essenziale di fatti essenziali» (Pavese 1998: 106), y por otro, cierta dimensión fantástica de la realidad - el poema como rapporto fantastico, apoyado en la noción de imagen, tal como Pavese la intuye, aunque no la define; imagen que está ligada a una determinada organización analógica, pero esencial, del paisaje ${ }^{22}$, con todos los elementos substanciales y formales que lo componen; exigencia que debería desembocar, de cara a los «poemas no escritos», en la búsqueda de una realtà simbolica, en la que los acontecimientos ocurrirían no porque así sean en el mundo natural (biografía y cronología) sino porque «così decide l'intelligenza», en función de la formulación de un «giudizio» (Pavese 1998: 118) ${ }^{23}$.

b. y, por otro (se opone), al simbolismo heredado, es decir, a una experiencia o añoranza de la realidad, con pretensiones de trascendencia: el juego peligroso en el

21 En la alianza perfecta entre la sintaxis de las ideas y la música de los fonemas.

$22 \mathrm{Y}$ es ese esencialismo materialista el que encuentra una difícil definición, no de cara a sí mismo, pero sí de cara a su 'acceso' a realidad simbólica, sin que entre en juego ningún elemento trascendente, es decir, irreal (metafísico) o mental (conceptual o retórico).

${ }^{23}$ Pero aquí, sí, Pavese abriría las puertas a una sublimación espiritual (conceptual) de la realidad. 
que se instala parte del Romanticismo y casi todo el Simbolismo (en gran medida ateo), tanto en la poesía como en el cuento fantástico, apostando por el alcance transcendente del símbolo: el más allá de la trascendencia inmanente ${ }^{24}$, que el arte combinatorio de las palabras permite; lo que conllevaría, de cara al proyecto de Pavese, en primer lugar, un ejercicio de mistificación pseudometafísico (inadmisible) y, en segundo lugar, la emergencia de una poética interiorista, decadente, incapacitada para llegar al nosotros y al ellos, tan esenciales en el proyecto existencial de nuestro autor. Pero también $t u$-no lo olvidemos ${ }^{25}$; es decir, conllevaría la vuelta el caldo de cultivo heredado del simbolismo decadentista ${ }^{26}$ de toda su primer poesía $^{27}$ - aunque sus elementos recorren de manera esporádica los textos de Lavorare, ${ }^{28}$ para reaparecer ampliamente en los dos últimos canzonieri, pero, ya, sin atisbos idealizantes.

c. una aprehensión, finalmente, ajena a cualquier aventura estética (en el sentido de "experimento gratuito" que pudiera tener esta palabra, en manos de los vanguardistas, sea verdad o no esa gratuidad), pues esta privaría a la poesía de su función objetivante: («raggiungere l'evidenza fantastica fuori di tutti altri atteggiamenti espressivi viziati, a me pareva, di retorica» (retórica si se mira hacia la tradición asumida como tópico,) para caer en el «slabrato lirismo degli immaginefici» (Pavese 1998: 108), como los experimentos vanguardistas ajenos a una experiencia del mundo y de la vida, y carente de la fuerza, muscolosa, que requiere todo naturalismo esencial; (herencia de E. Zola, creo, aunque indirecta, tal vez).

2. ${ }^{\circ}$ Vuelvo ahora sobre la segunda perspectiva de la que hablaba. Dejando de lado los problemas que plantea las nociones de immagine, de fantastico, y de realtà simbolica (nociones que como se puede sospechar no sólo crean problemas en sí, sino que también los crean coyunturalmente, al querer Pavese extraerlos de un contexto de tradición y de un contexto hermenéutico más o menos establecido, para insertarlos en el contexto de $s u$ "naturalismo esencial"), es evidente que la formulación de un proyecto que pretende llevar la poeticidad al terreno de un racconto fantastico y asentar ese racconto en el presupuesto de raccontare immagini, de «narrazioni d'immagini» (Pavese 1998: 118), hasta llegar a construir un argomento (y entiendo argumento, como la organización progresiva de un texto que pretende ser,

\footnotetext{
${ }^{24}$ Creo que este oxímoron explica con certeza el alcance del sueño y del fracaso simbolista.

25 Se podría, en efecto, estudiar la poesía de Pavese en función del predominio de estos pronombres, en un texto o en otro, existiendo una marcada evolución que nos lleva del yo/ tú de los primeros poemas, al ellos/ nosotros de Lavorare y de su entorno, para pasar, finalmente, al tu (casi exclusivo) de Verrà la morte e avrà i tuoi occhi,

26 Después de Baudelaire, Verlaine y Mallarmé, D’Annunzio, Guido Gozzano y tantos otros.

27 Que, tras los primeros poemas "renacentistas", se organiza, ya, como poema relato (de tonalidad romántica) más o menos desestructurado en su narratividad por las emergencias del yo lírico y los elementos analógicos (esencialmente adjetivales), propios del simbolismo decadente.

28 «Ogni viso contiene / comme un fruto maturo un sapore andato». «L'acqua / è la stessa nel buio degli anni morti». «Perdura una calma stupita / fatta anch'essa de foglie e di nulla». Poemas como Paesaggio VIII, La notte, estate y La voce podrían ser considerados en su totalidad como plenamente decadentistas; y no están solos, aunque lo que más me interesa de este aspecto es ver como poemas plenamente 'realistas' están salpicados con anotaciones decadentes.
} 
a pesar de todo evenemencial), en el que «l'immagine forse essa stessa argomento del racconto» (Pavese 1997: 117) es un proyecto (aunque aparentemente fracasado), de un alcance subversivo que atañe a toda la poética de los géneros; un proyecto que, a pesar del desmentido posterior, sigue siendo el proyecto poético de Pavese, sacralizando Lavorare stanca, frente al resto de la obra en verso. Una obra poética (ese resto), en mi opinión, con maravillosos versos aislados de intensidad casi petrarquista, en la primera parte, previa a su caminar hacia la experiencia de la poesía racconto, y con hermosos y sensibles poemitas en la tercera, no desprovistos de encanto desesperado, pero muy lejos de la intensidad poética y del alcance universal de la obra de algunos de sus contemporáneos.

En efecto, lo que está obsesionando a Pavese en sus poemas y en sus dos cortos ensayos (continuados de manera intensiva en las primeras páginas de $\mathrm{Il}$ mestiere di vivere) es el estatus insostenible de la poeticidad, en sí, cuando se la ha despojado de la tercera página (Mallarmé dixit), es decir, de la anécdota que la sostenía evenemencialmente (leyenda, elegía, idilio) y cuando se la ha privado del sostén lógico que permitía el desarrollo argumentativo, aunque velado, de un determinado concepto (Baudelaire, tras Allan Poe), como parábola o, sobre todo, como alegoría... el estatus insostenible de la poeticidad, frente a la narratividad y la discursividad, capaces de organizar, sin recurrir a ninguna de las otras dos instancias básicas del lenguaje, textos que son pura narración y textos que son puro desarrollo argumentativo. Es decir, lo que está planteando Pavese, más allá y más acá de la naturaleza argumentativa o narrativa de su propia dinámica mental, es la imposibilidad de una «poesía pura» que, salvando la cumbre del grito, del concepto metaforizado y de la anotación descriptiva minimalista (poesía pura de Juan Ramón Jiménez, copla, haiku), pueda organizarse en desarrollo textual, es decir, en poema. Ahora bien, asumido ese estatus insostenible de la poeticidad, que la experiencia simbolista ha intentado salvar mediante la estructuración metafórica dinámica del poema ${ }^{29}$ y su reducción de tamaño, con el fin de evitar la necesaria pero no deseada composición de un argumento ${ }^{30}$, Pavese se empeña en hacer poesía - pero sólo la puede hacer mediante la narración, mediante un racconto que no cuenta sino que es capaz de transformar los hechos, convirtiéndolos, sublimándolos, en imágenes.

Por eso, esa insistencia suya en definir el concepto de immagi y de fantastico (los pilares analógicos, semánticos, de la poeticidad tradicional, no sólo de la simbolista) y la voluntad de convertir el devenir de una imagen (irrealizada) en la materia misma del argumento (naturalista); por eso, su sensación de fracaso. Observemos, aunque sea de paso, que Pavese no presta mucha atención al otro pilar de la poeti-

29 Es una de las tesis de mi libro Teoría y práctica de la función poética, que ilustro, de manera esencial, con el análisis de de los siguientes poemas: La Chévelure, de Baudelaire, Las tierras de Alvargonzález, de Antonio Machado y Neiges, de Saint-Jonh Perse (Del Prado 1993).

30 Véase Le Lac de Lamartine, como prototipo de un poema romántico perfectamente (odiosamente) bien compuesto, en tres partes de amplitud equilibradas, como si se tratara de una narración; siendo la segunda, escrita en un tempo distinto y con cambio de voz del sujeto lírico (yo-poeta / yo-amante / yo poeta) como una piedra preciosa engastada, atemporal, en el devenir de la temporalidad: un momento de poesía pura vulgarmente sublime. 
cidad, el que articula en sintaxis y en prosodia la expresividad lírica. Su poesía tiene un alcance esencialmente semántico (simbolista, pues, en la búsqueda del más allá de las cosas y de las relaciones secretas entre estas) y muy poco expresivo (no romántico, pues, al no pretender la búsqueda del más allá del sentimiento). A este respecto, un ejercicio escolar de muy fácil realización sería estudiar cómo, a medida que avanza la obra de nuestro autor, van desapareciendo los signos materiales más aparentes de esta expresividad - Los $O h$, los $A h$, las exclamaciones, las interrogaciones retóricas, los puntos suspensivos y los adverbios de intensidad y de cantidad. Marcadores de la expresividad tan presentes aún en Baudelaire y tan ausentes de la poesía de Mallarmé, por dar dos ejemplos.

Ahora bien, si uno no quiere recurrir a las imágenes basadas en las analogías arquetípicas que sustentan las metáforas tradicionales (incluso las simbolistas) para organizar ese devenir argumental del texto, porque estas imágenes están bajo sospecha de simbolismo irrealizante o de esterilidad libresca, uno no tiene más remedio que asentar su noción de imagen en el nivel más objetivo, más natural, del término: en la oferta de imágenes que nos ofrece el sentido de la vista (sin que la vista, incluso distorsionada, se trascienda en visión) y, por ampliación analógica, en la oferta de los demás sentidos ${ }^{31}$.

La «narrazione d'immagine» (113) se convierte, finalmente, en descripción de un cuadro modificado fantásticamente por los juegos de los sentidos, es decir, de un cuadro en el que las múltiples actividades de los personajes, abortadas en simples gestos, son esbozos yuxtapuestos de una posible/imposible acción que casi nunca llega a culminarse; que nunca llega a organizarse en argumento; lo que pone en entre dicho (o sublima, desde el punto de vista referencial), la pretendida "avventura naturalistica» (117) a la que habrían avocado los intentos de Lavorare stanca. Este tratamiento de la realidad confiere a esos cuadros cierta dimensión surrealista ${ }^{32}$, a la par que naturalista. Pavese pasa, así, del símbolo (y de la metáfora) a la imagen, pero considerada ésta no en su acepción bachelardiana, sino como elemento de una estampa real, alucinada, yuxtapuesta a otro elemento; no como sustituto semántico, más o menos pertinente, de una operación metasémica, sino como deslizamiento temático, basado en una correspondencia viva y vívida (naturalista) - potenciada por la contigüidad y por contacto esencial de las cosas y de los seres ${ }^{33}$. Quedaría por fijar en qué consiste la esencialidad (biológica y espiritual) de esa contigüidad y de ese

31 No sé como aceptaría Pavese una lectura de la organización metafórica de un texto, en la que se pusiera de manifiesto la no pertinencia de su punto de vista sobre ciertos poemas simbolistas en los que la imagen sí es motor de una argumentación analógica (ver nota 30), desmintiendo la frase que resume su apostasía del valor poético de la imagen por él “descubierto", gracias a los esfuerzos de Lavorare stanca: «[...] che l’imagine fosse stessa argomento dal racconto si è chiarita falsa o per lo meno prematura. Tu hai sinora evocato figure reali radicandole nel loro campo con paragoni interni, ma questo paragone non è mai stato esso stesso argomento del racconto, per la sufficiente ragione che argomento era un personaggio o paesaggio naturalisticamente inteso [...]» (Pavese 1998: 117).

32 Surrealismo que nacería no de la visión transreal de los seres en sí (Rimbaud, en ciertos poemas de Illuminations) sino de las correlaciones 'irreales', insólitas, que seres muy naturales mantienen entre sí.

33 «Sforzo di rendere come un tutto sufficiente un complesso di rapporti fantastici nei quali consista la propia percezione di una realtà» (Pavese 1998: 111). 
contacto o comunión. (Pero aquí deberíamos abandonar la especulación formal y pasar a los análisis temáticos, en el sentido que Jean-Pierre Richard da ese término - en la dialéctica ascendente entre sensación, percepción e imaginario).

Ello quiere decir que la base de la imagen pavesiana está en los objetos que se encuentran y se mueven en el interior de un determinado espacio que, organizados por el deseo, la añoranza, la imaginación o la inteligencia, pueden llegar a componer un paisaje (un cuadro esencial) y que el motor formal de la invención de ese paisaje en escritura es la descripción.

Creo, por ello, que el momento cumbre del "descubrimiento" poético de Pavese no es I mari del Sud, (ensayo de racconto, pero sin el elemento alucinado, reconstructor, de los textos definitivos), sino el tercer poema recogido en Lavorare stanca, Paesaggio (y Pavese nos lo dice entre líneas, cuando nos explica como se gestionó este poema).

En efecto, el problema y su resolución no están en el racconto poema (este nos llevaría a pensar que hubo un momento, antes del Simbolismo, en el que casi todo poema era racconto (salvo alguna canción mínima y múltiples sonetos conceptuales renacentistas y barrocos que se articulaban como esbozos de argumentación), sino en la posibilidad de narrar imágenes: de convertir lo estático pictórico, visual, en dinámico lingüístico, argumental. No es nada desdeñable el hecho de que Paesaggio sea el título más repetido a lo largo del libro $(6+2)$; y ¿no podemos acaso afirmar que además del titulo que cada uno de los poemas lleva, casi todos ellos podían llevar como subtítulo el de Paisaje? Es un hecho: o como anotación de los primeros versos o como presencia diseminada, envolvente, en el conjunto del poema, la narración de un paisaje se conforma en múltiples ocasiones como el armazón que sostiene poéticamente el racconto.

El conflicto pavesiano, y por eso es interesante, más allá o más acá del valor en sí de la poesía de Pavese (y tengo que reconocer que Lavorare stanca y su entorno me gusta sobremanera), nos remite a un conflicto y a una frase similar, escrita casi un siglo medio antes: la de Chateaubriand, cuando al inicio de René (1802), el narrador/protagonista postula la posibilidad/imposibilidad de un relato que narre ideas (ideas, objeto hasta entonces reservado a la discursividad) y que narre sentimientos (sentimiento, objeto tradicional de la poeticidad lírica): el resultado final de la propuesta del gran escritor francés, abriéndose paso en secreto a lo largo de todo el siglo XIX realista, ha cristalizado la deconstrucción proustiana y joyciana del relato tradicional: un relato en el que, entre otras peculiaridades (para mí secundarias ${ }^{34}$ ), las bisagras que articulan y hacen progresar «los posibles lógicos del relato» ya no son sólo bisagras evenemenciales, sino bisagras semánticas de naturaleza emocional y, muy a menudo, bisagras analógicas; como en la progresión de los poemas de naturaleza romántica, en el primer caso, y en la progresión de los poemas de naturaleza simbolista, en el segundo. Con lo que ya no deberíamos hablar sólo de los posibles

34 Secundarias, porque ya existían con anterioridad: emergencia en el interior de la narración de fragmentos poéticos puros, de micro o macro digresiones argumentativas, relatos dentro del relato, proliferación metadiscursiva, soliloquio íntimo, etc. 
lógicos del relato, a la hora de estudiar su organización en argumento, sino que sería preciso hablar de los posibles analógicos (cuando no ilógicos) de este ${ }^{35}$.

Podría seguir argumentado en esta dirección, pero había dicho (y ya me había olvidado de ello) que a la par que una reflexión, que espero no haya sido demasiado borrosa, la relectura en paralelo de los textos de Pavese me había ofrecido una posibilidad honrosa a mi necesidad de elaborar una salida digna al enredo en el que me he metido.

La poética de Pavese se consolida, en torno a Lavorare stanca, en el punto de colusión (choque y pacto a un mismo tiempo) entre la materia narrativa que sustenta el poema y que tendería, necesariamente, por su propia naturaleza a articularse en narración, y la voluntad poética del escritor, que desarticula, que fragmenta, que repite (que musicaliza, en definitiva), a través de una presentación peculiar de los temas, esa materia narrativa; siendo siempre el resultado la creación de un paisaje que, aunque ya he empleado la palabra, calificaré, de manera definitiva, de alucinado; frente a simbólico o fantástico (términos, ambos, con cierta vocación de trascendencia, arquetípica o metafísica). Aprovechando la iluminación peculiar que de los cuadros propicia una sensibilidad determinada, se trata de ver en la realidad lo que los otros no ven, de un modo que los demás no son capaces de proyectar sobre las cosas, incluso en el interior del más crudo realismo. ¿Pero, no es este el fin de toda poesía que pretende serlo sin echar manos de trucos mistificadores? Por eso toda poesía auténtica es, a la par que simbólica, naturalista - naturalista de manera esencial.

Me apoyo para explicar este tipo de visión en el somero análisis del poema Casa in costruzione, elegido por mí como poema ejemplar.

$1^{\circ}$. La primera estrofa nos sitúa ya, a pesar del título del poema, en la plenitud naturalista, esencial, de este: en un paisaje campestre (el paraje poblado de cañaverales), donde el sol despunta de soslayo, pero donde se está construyendo la casa y trabajan los muratori; un paisaje natural, a punto de convertirse, sin embargo, en imaginario, debido a los juegos de la añoranza sensible (e insisto en la dimensión sensorial de la imagen) que recuerda la posibilidad pasada de poder, allí, «gettarsi sull'erba».

$2^{\circ}$. En la segunda estrofa, de golpe, con la irrupción de los muchachos («i ragazzi cominciano»), la casa, de la que nada nos ha sido descrito aún, adquiere una dimensión casi "fantástica", debido a su condición de objeto inacabado frente al cielo: el sol «piú alto» y los pilares «isolati nel cielo», junto a los huecos de las ventanas «i mattoni scoperti», se llenan de azul y de cielo, convirtiendo un espacio de juego, mejor que el bosque y que la carretera, en un espacio de contemplación: el decorado, casi, de una posible transfiguración; pequeño monte Tabor de la infancia; «e ai ragazzi è una gioia vedersi dal fondo / sopra il capo i riquadri del cielo», deseando, incluso, la llegada de un agua lustral caída desde esas aberturas celestes.

$3^{\circ}$. La tercera estrofa continúa esa visión alucinada, entre lumínica y pluvial, «tra i muri / si vedevan le stelle». Pero, poco a poco, la realidad de un paraje no aún urbanizado, medio salvaje todavía (y para los chicos de pueblo sabemos hasta qué

\footnotetext{
35 Pero esto ya lo puse de manifiesto en Prado (1983).
} 
punto estos espacios, en las afueras, son lugares privilegiados para los juegos marginales), la realidad naturalista va cobrando importancia de nuevo: el fuego encendido en el interior de la "casa", las pedradas imprevistas que pueden alcanzar, las bichas que pueden caer de las paredes, etc. Hasta la llegada del viejo (vagabundo): sólo él sabe lo que ocurre de noche en esa casa en construcción; observación que instala los muros inconclusos, pero que ya contienen un espacio, en la dimensión del misterio - de lo "naturalmente" ignoto, porque no se deja ver. Sin prestar atención a las consideraciones sociales que aparecen de soslayo en esta parte del poema («[...] altri si fanno la casa / col sudore e lui sensa sudare ci dorme» y la alusión sexual, casi necesaria en todo cuadro de Pavese ( $\ll \mathrm{Si}$ capisce una coppia in un prato... ma...»). Una observación es precisa aquí, relativa a la identificación, a la asimilación esencial entre el cuerpo humano y el ámbito cósmico en el que vive (como en el caso del ermitaño del primer Paesaggio: el viejo del poema que analizamos «ha la barba strinata / dalla vampa e ha già presso tant'acqua, che, come il terreno / non potrebbe cambiare colore».

$4^{\circ}$. La cuarta estrofa recupera la construcción (realismo) de la casa; mejor, el descanso «all'ombra» que se toman los muratori después de haber trabajado. Ese momento de descanso (¿cuántas veces trabajan de verdad, directamente, los personajes que desfilan por Lavorare stanca?) da pie a la emergencia de un conjunto de elementos naturalistas: el sol en su apogeo, los ladrillos que arden al sol, las bichas que un día sí han saltado desde los muros, los animales sedientos, las colinas que parecen arder, el viejo que atraviesa las viñas, robando, de nuevo, los chicos que juegan, ahora en el puente, la pedrada que puede surgir y, de hecho surgió un día, rompiéndole el cráneo al patrón, lo que causó que el trabajo tuviera que detenerse, al tener que llevarlo al arroyo para lavarle la herida. Todos, elementos naturalistas, esenciales, en la vida de una aldea; pero que en ningún momento se organizan en narración; sólo se disponen, de manera caótica a lo largo y ancho del poema, conformando una escena, un cuadro en movimiento que nos sugiere las acciones que podrían haberse desarrollado en argumento en torno a ello. Pero esta observación puede ser aplicada a todo el poema: ese ser sin actuar, ese estar en la realidad pero como queriendo salirse de ella; ese ser materia y materia trascendida por la misma situación material en la que se inserta; a todo esto podemos llamarlo naturalismo esencial (pues carece de voluntad de accidente, de voluntad de existencia) y, si se nos antoja, realismo simbólico - aunque nada de mágico tenga.

Tras este breve análisis (más glosa que análisis) y antes de proseguir con mi demostración, me permito recordar la importancia que tiene la luz en el nacimiento de estas imágenes alucinadas; razón por la cual, el amanecer (nell'alba) y el atardecer (nel crepuscolo) son los momentos del día privilegiados en Lavorare stanca, siendo el pleno mediodía (con su sol deslumbrante, la vampa del sole) y la noche $(\text { sta notte })^{36}$ dos contrapuntos brutales para la captación de la realidad en la luz alu-

36 Observemos, de paso, que estos momentos del día son espacios de tránsito en la actividad laboral (amanecer y anochecer, mediodía y media noche): el poema huye así de los espacios laborales tradicionales, es decir de los momentos de actividad "histórica" que configuran la historia de lo cotidiano social. 
cinante (y juego con la falsa etimología de alucinación), por exceso o por carencia; ello, sin olvidar la importancia de la nebbia, del buio y de la distancia (la finestra que se abre, se entorna o permanece cerrada o abierta a lo lejos) en el paisaje pavesiano; (pero este apartado nos llevaría a otros niveles de análisis en su obra ${ }^{37}$.

Ahora vuelvo a mi tesis: para conseguir este empeño, este maridaje entre narratividad y poeticidad, Pavese recurre a mecanismos propios de la preceptiva poética tradicional, usados aquí con una intención perversa, etimológicamente hablando: de cara y contra la organización de una posible narración o de cara y contra el vuelo de un posible poema, según se mire.

\section{Narratividad y poeticidad en Lavorare stanca}

Para llevar a cabo la demostración de estas afirmaciones deberíamos estudiar el problema articulado en tres etapas:

a. Ver cómo la posible o incipiente narración queda reducida a descripción, mediante la anulación, la fragmentación o la congelación del movimiento narrativo.

b. Analizar los distintos procedimientos poéticos que llevan a la deconstrucción (prefiero el neologismo castizo, desbaratamiento) de la descripción misma, latente en el texto.

c. Rastrear la presencia de este modo de composición, más allá de las fronteras de Lavorare stanca, como procedimiento germinativo del conjunto de la obra del autor.

Con el fin de lograr un acercamiento rápido y pedagógico, en función del espacio del que dispongo y de la intención que me guía (este apartado sería más bien objeto de un seminario), voy a fijarme aquí en los seis poemas siguientes; pero podía haber elegido cualquier otro del libro - salvo I mari del Sud, tal vez.

Paesaggio (II) y Lavorare stanca, ambos pertenecientes al cuerpo central del libro; Il carrettiere y La voce, pertenecientes a Poesie aggiunte; Il piccolo pesce rosso, perteneciente a Le febbri di decadenza, anterior a Lavorare stanca y The cats will know, perteneciente a Verrà la morte e avrà i tuoi occhi, último libro de versos del autor.

Obtenemos así un doble contrapunto: primero, en el interior de la masa poemática perteneciente a Lavorare y, luego, en la relación de esta masa con su exterior. Sin pretender que estos seis poemas sean metonimia perfecta del conjunto de la obra, pero sí un muestrario, cuyos patrones de composición aprueban una reválida más que justificada en ese conjunto. Por otro lado, un poema como La voce me permite afirmar que, incluso en el interior más puro, más selecto de Lavorare pervive una poesía sin pretensión narrativa, propia del simbolismo decadente, asentada sobre un momento interior del yo lírico, carente de toda sustancia evenemencial cronológica, incluso fragmentada, tal como la podemos encontrar en otros poemas.

37 V. con respecto al tema de las ventanas y de las fachadas (lejanas) en la descripción Bonnefoy (1977). 


\subsection{De la narración a la descripción (la anécdota cuajada en cuadro)}

\subsubsection{Paesaggio II}

Siguiendo un procedimiento habitual en Pavese, el poema recoge elementos anecdóticos presentes en otros poemas (anteriores), en esta caso « Mio povero vecchio / che in questa notte nebbiosa d'inverno»... (Rinascita, 1927). Con un ritmo análogo y con una análoga presencia del sujeto lírico; sin embargo, este pasa de ser el yo lírico romántico (herencia directa de Leopardi -«Oimè,/ cuanto somiglia al tuo costume il mio»-y de Baudelaire) en el que un ser miserioso y solitario se instituye en espejo existencial del "poeta", al yo testigo del espectáculo naturalista, connotado simplemente, aquí, por la apelación Il mio vecchio ${ }^{38}$.

El racconto podía haber quedado reducido u organizado en función de una estructura narrativa de gran sencillez, de gran esencialidad naturalista: el viejo viñador recorre sus viñedos (que se encuentran en la parte baja de la colina) y comprueba como faltan algunos racimos de sus vides, poco productivas y comidas por la sombra que reina en la vaguada. Mientras camina, surgen en él dos pensamientos: la envidia que le producen los campos de arriba, lassú (voz repetida en varias ocasiones), donde los racimos de otros propietarios arrastran por tierra, tan grades son y tanto pesan, y el temor de la llegada de los ladrones; temor, ante el que haría frente con su fusil desde la casa, si sus viñas estuvieran en la parte alta, donde se dibujarían las siluetas de los intrusos, comprobando que dicho fusil no le sirve abajo, «al fondo», en sus viñas, porque «dentro il buio non c'è che fogliami».

Tenemos elementos suficientes para una narración que podría haberse articulado narrativamente entre la realidad y el deseo; la realidad y cierto rencor salpicado de miedo; un cierto complejo de inferioridad y la envidia del otro, subyacente en casi toda conciencia campesina

Sin embargo, esta narración no llega a alumbrarse, no se conforma en argumento tradicional, por distintas razones:

a. Los verbos de acción (que serían de acción) referidos al protagonista no están casi nunca ( hay algunas excepciones: «Il mio vecchio ha trovato», «il mio vecchio [...] ha la mano», «alza il capo», «[i ladri] entran dentro alla vigna saccheggiano le uve») ni en presente, ni en pasado (tiempos propios de una acción que ha ocurrido o está ocurriendo de manera singulativa ), ni en imperfecto (tiempo propio de una acción que ha ocurrido de una manera iterativa - siempre según la terminología de G. Genette;

b. Los verbos de acción referidos al protagonista y a las comparsas están casi siempre en futuro o en condicional (tiempos de lo no ocurrido o de la hipótesis, tiempos, por consiguiente, que sitúan al personaje fuera de la acción, en sí, y de la

38 Como en muchos poemas que podríamos calificar de "sociales", en los entornos del Simbolismo. Y pienso en François Coppé - Los miseriosos y Paseos e interiores - y en Arthur Rimbaud - que para este menester es, aunque sorprenda, el discípulo odioso que se ríe del maestro imitando al maestro, a veces en serio, a veces medio en broma - Los viejos coppés). 
realidad): «si vedrebbero i ladri», «se vengono i ladri», «sono gente da farle», «Se avesse la vigna lassù», «il mio vecchio farebbe»; en ocasiones los verbos de acción pierden su potencial activo al estar modalizados por verbos o partículas indicadores de la apariencia y de la posibilidad: «se vengono [...] salta in mezzo ai filari e gli fiacca la schiena», «gli pare che arrivi»;

c. Contrariamente (y como es natural), todos los verbos referidos a la naturaleza están en presente de presencia, con lo que se hace patente su realidad esencial y estable: «la collina biancheggia», «i filari son tutti nell'ombra», «la vigna e già scarsa», «Lassù brucia il sole», «la terra è calcina», «l'uva atrascina per terra», «dentro il buio non c'è che fogliami», etc.

Todos estos elementos morfosintácticos afianzan la supremacía del cuadro real (y del deseo) sobre la posible acción, y tanto el protagonista como los demás personajes pasan a formar parte de un universo que serviría de base para una acción hipotética, en medio de un marco (mejor, de un ámbito) material: la campiña, el cosmos humanizado, que afirma su supremacía sustancial y perdurable.

\subsubsection{Lavorare stanca}

El poema que da título al libro es el paradigma de cuanto acabamos de decir. Estamos ante un hombre («quest'uomo che gira / tutto il giorno le strade») que vaga por el pueblo, por las calles y por las plazas desiertas, como suelen hacer los chiquillos ociosos, posiblemente en busca de una mujer que no encuentra, mientras que, posiblemente, la encontraría de ir por los caminos, dispuesta a seguirle ella hasta su casa.

En esta ocasión, salvo la acción inicial, todo el texto se instala en la dimensión hipotética de lo que debiera ser, para el hombre, en contraposición a lo que sí puede ser para cualquier muchacho; con lo cual se disloca de manera brutal el punto de vista que rige el poema: «traversare una strada per scappare di casa / lo fa solo un ragazzo». Y aquí, en la ausencia casi absoluta de verbos de acción, el poema está devorado por los infinitivos que marcan una acción substancial, en abstracto (traversare, scappare, esser (2), girarle, parlarle, fermare, deciderla a vivere, restare), ligados, casi, a un imperativo categórico relativo a lo que es pertinente hacer, o por los futuros y los condicionales (fossero, sarebbe, verrebbe, sarà, vorrebbe) que, desde el punto de vista funcional, van en la misma dirección.

$\mathrm{Si}$ en el poema anterior nos instalábamos en el estatismo de unas acciones que podrían haber sido pero que no son, pues no se dan las circunstancias para que sean, este poema nos lleva a un espacio moral en el que las acciones posibles deberían ser o no ser en función de la condición social (la edad) de los protagonistas. Mientras esta indefinición real determina a las personas (los posibles actantes de la acción), tres realidades espaciales afirman su estabilidad imperiosa, como marcando los límites del mundo real (el pueblo, aquí, con sus aledaños, pero en ausencia de cualquier elemento de naturaleza cósmica - los consabidos árboles, colinas, río, etc. - sólo se hace alusión a «un viale di inutili piante», así, en abstracto) y los límites de la necesaria pero imposible acción: le strade (a veces vuote), la casa (abandonada y que 
espera), y le piazze (siempre vuote) aparecen y reaparecen por el texto, trazando su trenzado semántico y musical, para fijar las coordenadas conceptuales del poema: «Val la pena esser solo, per essere sempre più solo?»

Después de este primer acercamiento a los poemas de Pavese podríamos resumir o agrupar estos procedimientos de la siguiente manera; contando, claro está, con el hecho de que cada poema selecciona y hace un uso específico de los procedimientos que favorecen su intención creadora:

a. Presencia de una pluralidad de personajes heterogéneos, si tenemos en cuenta el espacio breve del poema; lo que propicia una proliferación larvaria de varias posibles anécdotas (o argumentos) narrativas;

b. Focalización del cuadro (o cuadros) desde distintos puntos de vista, en función de estos personajes, lo que podría provocar varias instancias narrativas sin interferencia o conjunción con las que podrían surgir, a su vez, de los demás puntos de vista posibles. En consecuencia, esta variedad de puntos de vista permite o favorece que los personajes sean abandonados por el narrador en medio de su "acción", llevando su atención a otros personajes; lo que fragmenta y hace imposible cualquier progresión narrativa de cualquiera de las "acciones" posibles.

c. Presentación iterativa y alternativa de los personajes, que repiten o no acaban sus gestos, o que no llegan a tener gestos, sino a formular solo posibilidades -miedos o deseos;

d. Frecuente empleo atemporal de los verbos (futuros con valor de hipótesis, condicionales e infinitivos) mezclados con verbos de acción a los que, en cierto, modo desdicen, o de verbos de acción, modalizados por verbos de pensamiento: pensar, creer, soñar (ver, por ejemplo, el uso repetitivo de «Uno crede...» en el poema Simplicità)

Los personajes pasan, así, de ser posibles actantes de una anécdota (posible argumento) a ser comparsas o figuras de una escena, de un cuadro; un cuadro ligeramente movido, si se me permite el símil fotográfico o siguiendo con el símil de misma naturaleza, de dos (o más) fotografías casi idénticas, pero distintas, pues, con los mismos personajes, en la misma situación, han sido tomadas con intervalos de tiempo suficientes para que alguno de ellos se haya movido - e incluso no salga ya en la segunda foto.

\subsection{La deconstrucción de la descripción (redundancias, traspasos y corrimientos semánticos)}

\subsubsection{Il carrettiere y La voce}

En el primer poema, estamos ante una escena de la vida cotidiana campesina: un hipotético carretero; una hostería -su tibieza y su acogida, sus gritos; el despertar del día que se resiste- dialéctica entre el alba y la oscuridad -rayo de luz; ojos que remueven la sangre; las carretas por los caminos; sacos que poco a poco cobran vida- realidad y recuerdos. Todo, con los elementos realistas que se enlazan de manera irreal, a base de cruces repetitivos y de yuxtaposiciones; en este caso, en ausencia (aparente) de metáforas, como luego veremos. 
En este poema, la destrucción del posible relato no es un problema de falta de acción, cuajada por un uso peculiar de los tiempos verbales. Sabemos que el carro avanza, cargado de sacos, convirtiéndose en el auténtico protagonista de una historia esencialmente dinámica $-\mathrm{y}$ todos los verbos "esenciales" los hallamos en presente de acción, siendo el verbo más significativo del poema el verbo $i r$ - empleado en presente de indicativo: «Va col carro un topore», «va col carro un ricordo», «Lo stridore piú roco del carro che va». Acompaña a este verbo otro, muy propio del avanzar de los carros por los caminos del campo; se trata del verbo scuotere (sacudir, mover agitar): «Lo stridore del carro scuote la strada», "Anche i sacchi [...] scuotono...». De modo sorprendente, es este verbo el que aquí desbarata la narración o, mejor, el que la sublima, situando el cuadro, que podía haber sido de un naturalismo campesino esencial, en otra dimensión: la de un paisaje interior - el paisaje interior que nace rítmicamente del recuerdo. Poco a poco no es ni la posada con sus tibiezas, ni el carretero, ni el carro con sus sacudidas, lo que interesa, sino el cargamento del carro: los sacos; que, de sacos reales, acabarán siendo los sacos del recuerdo.

Aquí no se trata ya de un cierto estatismo que configura un cuadro alucinado con la superposición de dos o más fotografías en las que los personajes se han movido; aquí la no progresión desemboca, apoyada en esos mismos elementos repetidos, en la creación de un cuadro que se sitúa en otro nivel, en función de unos sutiles desplazamientos, corrimientos, de la materia semántica. Varios son los procedimientos que el poeta sigue para obtener estos resultados

\subsubsection{Desplazamientos metasémicos fundados en la analogía}

No es mi intención centrarme en estos procedimientos que podríamos considerar como los pilares básicos de toda la poesía simbolista y post-simbolista (analogías sensoriales y trans-sensoriales), incluido el surrealismo (analogías irracionales subconscientes) y sus aledaños, pero también los distintos experimentalismos de la vanguardia (analogías gratuitas o aparentemente gratuitas). No es mi intención por una razón muy simple: Pavese quiere crear poesía al margen de estos procedimientos que, con razón o sin ella, no considera válidos y que, por consiguiente intentaba evitar, aunque no siempre lo consiguiera.

De haber sido mi intención fijarme en estos procedimientos mi discurrir hubiera debido adoptar un presupuesto temático, como ya he dicho, en función de la búsqueda e invención del universo imaginario pavesiano cuya raíz estaría, como siempre (desde esta perspectiva crítica), en la dialéctica lingüística entablada entre sensación y percepción personales ${ }^{39}$, por un lado, y elementos arquetípicos heredados

39 Dependientes (y en coherencia interna) de una infraestructura psicosensorial, según la terminología acuñada por mí en la formulación teórica del tematismo estructural. 
por otro. El hecho de que la obra de Pavese (poética o narrativa) permita pensar en esta posibilidad ${ }^{40}$ no empaña para nada la voluntad y la audacia de su proyecto poético.

Ahora bien, con el fin de probar que, a pesar de todos estos procedimientos existen, aunque sólo ponga de manifiesto algunos ejemplos, voy a recurrir a dos ejemplos que pueden ser cabecera de dos procedimientos casi generalizados en la obra de nuestro poeta.

El primero atañe a los desplazamientos sémicos debidos a las analogías sutiles que se establecen en el nivel de la sustancia, a pesar de la diversidad de los accidentes en los que esta se manifiesta; como es lógico, tienen su base en las correspondencias sensoriales puestas en evidencia por Baudelaire - y por Proust, de manera más generalizada ${ }^{41}-$ «ogni odore e un ricordo»-, (40) y que son la esencia de la metáfora simbolista. Me permito recordar uno que me es muy querido, pues aúna dos elementos muy pavesianos -el vino y la niebla - «E anche il vino no sa che di nebbia» (Semplicità). Y este otro, nacido de la analogía entre la tela y el aire, pero apoyado en el texto de Pavese por un juego sutil de aliteraciones: «I vestiti diventano vento le sere di marzo», perteneciente al poema Una stagione -todo él, delicioso canto al cuerpo jugoso de la mujer bañada en el viento-.

El segundo procedimiento atañe a la contaminación o al trasvase semánticos por contigüidad que se puede llevar a cabo entre un ser y otro ser: la contigüidad accidental y/o esencial en la que viven hombres, mujeres y animales - perros y gatos, en particular -, inmersos en los elementos primarios del paisaje, tanto en su dimensión cósmica como en su dimensión pueblerina, y que conlleva o presagia, casi siempre, una tensión sensual - a menudo sexual; pero no siempre, como es el caso del ermitaño de Paesagio (12) o del viejo del Paesaggio que hemos analizado páginas más arriba (22). Esa contigüidad de dos seres que acaban asumiendo elementos esenciales el uno del otro, genera una estructura especular, a veces poliédrica, de la realidad, apoyada por la presencia de partículas (preposiciones, adverbios) o de adjetivos que van creando, a la par que estructuras anafóricas (de las que luego hablaremos) paralelismos sintácticos y semánticos que consolidan la dimensión especular que pone en relación a los diferentes seres que conviven en el interior del poema.

Me permito recordar dos casos de tensión semántica, por simple yuxtaposición especular, casi antagónicos. El primero pertenece a Un piccolo pesce rosso, en el que mediante la repetición de ora, última palabra del verso que introduce la estrofa dedicada al alma del poeta («La mía anima ora / è un abisso dell'oceano...») y última palabra del verso que introduce la estrofa final, dedicada al pez rojo («Il pesce rosso ora / s'agita nel cristallo...»), se opera todo un trasvase de substancia semántica del pez al alma y del alma al pez (cansancio, ahogamiento, miedo, temblores, fiebre) hasta conformar la presencia de ambos en una identidad fraguada por su vida

\footnotetext{
40 Pienso en el poema «autobiográfico» Mania di solitudine, crucial desde el punto de vista del estudio de la estructuración psicosensorial del universo pavesiano.

41 Aunque ignoro la influencia directa del novelista francés en la obra de Pavese. (Esas "influencias directas" a veces no dicen nada o dicen menos que las influencias ambientales de una época).
} 
en "el agua". El segundo ejemplo pertenece a uno de los poemas más naturalistas de toda la obra del poeta, Il dio-caprone, pues condensa todos los fermentos (sensoriales, sensuales y sexuales) de los que hablábamos, de manera brutal, en una larga y densa página. Su organización, a este respecto, es esencialmente poliédrica.

Si el primer procedimiento (el de los cambios metasémicos) es producto de una herencia (las correspondencias analógicas que existen entre los seres, en el interior del uni-verso, propio del Simbolismo), este segundo brota de la mismísima infraestructura psicosensorial pavesiana, de la convivencia esencial de los seres -seres humanos y no humanos, seres (llamados) vivos y seres (llamados) muertos: es el fundamento de la esencialidad naturalista de su visión del mundo; un nuevo punto de contacto, a mi entender, con el naturalismo zoliano, más cercano a un panteísmo materialista ${ }^{42}$ que a una teoría pitagórica, en función de la cual la diversidad de los seres participa de lo uno y, por ello, son causa o razón de secretas correspondencias:

La campagna è un paese di verdi misteri

al ragazzo che viene d'estate. La capra, che morde

certi fiori, le gonfia la pancia e bisogna che corra.

Quando l'uomo ha goduto con qualche ragazza

- hanno peli là sotto - il bambino le gonfia la pancia [...] ( Pavese 1998: 69).

Y los intercambios semánticos debidos a la contigüidad de convivencia se van desplegando de este modo a lo largo de todo el poema, bajo el signo del dio-caprone.

\subsubsection{Procedimientos morfosintácticos ligados a la repetición}

Afirmar que la poeticidad es sólo redundancia, ajena a la progresión sintagmática propia de todo procedimiento lingüístico (basada en la articulación de sujeto + verbo + predicado), es una solemne, aunque sapientísima, tontería. Ignorar que el poema (más allá de una posible función poética final) es redundancia, al atenernos a la función instrumental de su organización, tendente a lo musical, es desconocer la historia mundial de la poesía y pensar que 25 años (no plenos) de ésta son capaces de anular siglos de historia.

Por otro lado (y en sentido contrario), no darse cuenta de que la redundancia (repetición y vuelta atrás del texto), propia de la naturaleza musical del poema, es (o puede ser, al menos) un estorbo para la naturaleza sintagmática de la palabra y de sus dos manifestaciones más aparentemente sintácticas ${ }^{43}$ (el discurso narrativo y el discurso argumentativo ${ }^{44}$, cuya naturaleza es esencialmente progresiva, sin vuelta

\footnotetext{
42 En contraposición, no olvidemos el contexto religioso en el que la Naturaleza traza, en el poema fundacional de Baudelaire, la red de sus secretas Correspondences.: «La Nature est un temple où des vivants piliers....».

${ }_{43}$ Remito a mi estudio acerca de las consideraciones que hace Beaumarchais sobre las (malas) relaciones existentes en la ópera entre relato y música (Del Prado 1995).

${ }^{44}$ El hecho de que la poesía moderna apueste (desde Un coup de dés...) más por la semántica que por la sintaxis es la prueba más flagrante de esta afirmación.
} 
atrás, con el fin de llegar al desenlace de la acción o a la conclusión de la argumentación)... no darse cuenta de ello impide situar el análisis de la composición de los textos literarios en la perspectiva necesaria para ver su especificad más pura o sus manifestaciones híbridas -en el respeto o en la subversión de los géneros y subgéneros-.

Esta reflexión teórica es necesaria aquí, si como afirma el propio autor y hemos creído demostrar nosotros, la aventura poética de Pavese se asienta en la confluencia entre la narratividad ${ }^{45}$ y la poeticidad ${ }^{46}$, con la pretensión de elaborar un poema racconto.

En efecto, cuando analizamos la poesía pavesiana nos sentimos en el centro mismo del imperio de la repetición: cadenas repetitivas recorren todo el texto; podemos encontrarnos con una sola cadena, en la que domina una sola palabra o con varias; siendo lo habitual varias (dos, tres, cuatro); con lo que el poema se organiza en función de un trenzado semántico y musical que progresa, como las trenzas de una cabellera mar, como la música, a oleadas reversibles. Rompiendo, dificultando, liando, desbaratando (decíamos antes) la posible organización sintáctica del poema y sustituyendo ésta por una progresión a la vez semántica y musical - la esencia misma de la poeticidad instrumental, desde mi punto de vista, tal como la analizo en Teoría y práctica de la función poética.

Veamos (ya fuera de los poemas elegidos como prototipos para este estudio) algunas de estas cadenas repetitivas.

En el poema Semplicità nos encontramos: «l'uomo solo» (4 veces), «uno crede» (3 veces). En el peoma L'instinto: «cane/cagne» (7 veces), «l'uomo vecchio» (4 veces), «istinto» (3 veces). En el poema Paternità:, «l'uomo solo» (6 veces), «mare» (5 veces), «letto» (3 veces). En el poema Lo stedazzu: «l'uomo solo» (5 veces), «mare» (4 veces), «accadere» (3 veces), «accadere nulla» (4 veces). En el poema Gelosia: «l'uomo vecchio» (5 veces), «donna» (5 veces), «nell'ombra» (3 veces). Y todas las repeticiones atañen, desde el punto de vista temático, a elementos esenciales del poema.

Si he elegido como muestrario estos poemas, ello se debe a que componen lo que he llamado con anterioridad el micro-canzoniere que he bautizado con el título especular L'uomo solo / l'uomo vecchio, verdadera rapsodia en el que la repetición, con sus variaciones, de uomo aparece musicada semánticamente hasta 23 veces, lo que le da una consistencia de poema sinfónico de una enorme y eficaz poeticidad. Pero no es el tema musical el que ahora me interesa, sino la contribución de la repetición a la configuración del conjunto de impedimentos que hacen posible la destructuración de la narración. La repetición crea los juegos poéticos musicales de la redundancia, pero relanza el poema, en deriva, si no actancial (entonces tendríamos narración), sí, al menos, semántica y temática hacia su resolución definitiva del cuadro. Una cadena similar, al menos en apariencia, a la cadena metafórica simbolista; pero,

45 Esencialmente sintagmática, en su desarrollo temporal (como historia).

46 Accidentalmente (o esencialmente - ¿quién sabe?) paradigmática en su superposición, en su saturación de códigos, registros y nominaciones, superpuestos para designar a una misma realidad. 
como ya hemos visto, de naturaleza no metasémica: no hay trasvase de semas sino puesta en evidencia de semas que las diferentes palabras (¿las diferentes realidades?) ya compartían, en función de una convivencia pánica.

Ello tiene varias consecuencias de cara al tema que nos ocupa:

El trasvase de materia (agente) de un elemento a otro, de un ser a otro (animados o inanimados, poco importa): la donna puede sentir primero la «streta dell'uomo», luego la «stretta di un altro ricordo» y, mediante este enlace, la «stretta de un uomo» preciso, aunque no el que en ese momento está presente (Gelosia).

El trasvase de materia (sustancial y formal) de un objeto o personaje a otro: en el poema Il carrettiere, el «carro (5) scuote la strada», «quegli occhi scuotano il sangue», «anche i sacchi scuotono», pero como el ricordo, organizado a su vez en otra cadena repetitiva («un ricordo già desto di parole», «il ricordo di ieri», «il ricordo si stringe ai sacchi»), el ricordo también scuote y «s'affonda nell'ombra di ieri / dove balza il camino e la fiamma viva» - como si del carro se tratara.

Por el mismo procedimiento, sin que medie, una vez más, metáfora alguna, en el poema $L a$ voce, «il silenzio (5 veces repetido, con distinta calificación) della camera sola», ya fresco, con ocasión de su segunda aparición, asumirá, al final del poema, las cualidades de la voz (6 veces repetida), rauca e dolce», «rauca e uguale», hasta convertirse (el silencio), en el último verso, en «rauco e somesso», como lo era la voz.

Desde este punto de vista (y para mí es una comprobación esencial), el texto de Pavese se convierte en el imperio del accidente flotante de la materia, que cristaliza o no en adjetivo. Ahora bien, este predominio de lo adjetival no sirve habitualmente para calificar emocionalmente al sustantivo (tal como era su función en la poesía de signo romántico), siendo un elemento morfológico esencial de la modalización enfática propia del yo lírico; aquí lo adjetival es el odre lleno de sustancia vital, el recipiente que los sustantivos (los seres y las cosas) se pasan los unos a los otros, para impregnarse de él, para beberlo, para llenarse de una misma esencia, poniendo de manifiesto que más allá o más acá de su singularidad conceptual abstracta (hombre, árbol, perro, casa), su epifanía al mundo (su realidad esencial) se hace en la comunión de unas calidades vívidas, biológicas, que comparten con los demás, y que sólo pueden ser captadas y asimiladas gracias a manifestaciones que pertenecen al mundo de los sentidos: sensoriales, sensuales y sexuales. Y esa comunión es la que instala la realidad pavesiana en su peculiar naturalismo: en su paisaje esencial pánico, aunque despoblado de dioses.

\subsubsection{A modo de epílogo: la modulación semántica y el poema musical}

Es sorprendente: cuando se leen por primera vez los poemas de Lavorare stan$c a$, tal vez llevados por el empeño del poeta, que pretende hacer una poesía con procedimientos ajenos a los que hasta entonces se han empleado comúnmente (excepción hecha del poema en prosa), lo que más llama la atención, lo que más seduce, no es la musicalidad de estos poemas.

Lo que primero llama la atención es, en medio de cierta percepción de una tosquedad primaria, el esfuerzo, el trabajo, de la poeticidad por convertirse en poema 
-un poema diferente-; y en segundo lugar, llama la atención la paulatina captación de un universo imaginario impregnado de conciencia cittadina (pueblo y campo), en el que los sentidos van cobrando una presencia avasalladora.

Ahora, a mí, después de pelearme durante años y medio con estos poemas, más allá de cuanto he dicho desde el punto de vista técnico o conceptual, lo que me llama la atención, lo que me subyuga, es una imponente musicalidad que no tiene, como alguno podría creer (y muchos han dicho), su fundamentación en ese verso "épico", narrativo, con su cadencia regular, monótona, rota, de vez en cuando, por las alianzas métricas contra natura, a las que hacíamos alusión al principio del estudio. (Atención: no dejo de lado la musicalidad narrativa de estos versos - creo que esta dimensión me ha servido para apoyar el desarrollo de mi tesis). Me refiero ahora a otra dimensión de esta musicalidad, más tradicional, si cabe - aunque estos elementos sean tratados de soslayo, como arcos en este viaje. Ello se debe, esencialmente, a dos razones: la primera no la he mencionado hasta ahora, se trata de la riqueza musical de las aliteraciones que salpican de aquí y de allá los textos de Pavese; la segunda es consecuencia de cuanto venimos analizando: nace de las cadenas repetitivas que compensan, con gran eficacia musical, la ausencia de rimas tradicionales.

Las aliteraciones; por mi propio placer, me permito recordar aquí algunos ejemplos:

«Poi ci sonno le bisce che scendeno i muri» (38); «La prigione pigliava la pioggia, in prigione la vita / non finiva, ogni giorno...» (45); «Papà beve al tavolo avvolto da pergola verde» (32); «e si stringono e tremano intorno alle donne che passano» (24); «ancor gelida e torba del sonno notturno» (25); «sola e nuda nel buio quando muta la luna» (59); «e poi ballano tutti, tenendosi ritti e ululando alla luna» (68) «lo stridore piú roco del carro che va» (90), etc.

Las cadenas repetitivas; y me permito volver, con el fin de rematar mi estudio, también musical, sobre los poemas La voce y El carrettiere.

\section{La voce}

a. La estructura musical del poema se inicia con una palabra en apariencia insignificante: «ogni» (cada y todo); sin embargo, esta insignificancia es sólo aparente: la conjunción de cada y de todo sitúa a la palabra «ogni» en el centro de la experiencia existencial de la repetición y, en cierto modo, de la clausura y del agobio (y del tedio) que esta repetición existencial puede implicar. Así, «ogni» puede ser captada como la piedra angular del texto, cuya modulación se va a prolongar justo hasta al verso central del poema, creando algo así como el ámbito de la experiencia de la temporalidad en el que el poema se desenvuelve; al mismo tiempo, sus complementos (e invierto la perspectiva lingüística) van introduciendo los dos elementos semánticos incidentales del poema - giorno y gesto: «Ogni giorno» (v. 1), «ogni gesto» (v. 2), «ogni giorno» (v. 3), «ogni giorno» (v. 7), «ogni gesto» (v.12).

A la sombra de «ogni», mientras «giorno» va a permanecer a lo largo del poema con su simple valor de focalizador temporal, «gesto» o «gesti» va a ir adquiriendo una carga semántica cada vez más importante, contraponiéndose al gran tema 
semántico y musical del poema -la «voce»-, y llevándonos al desarrollo final de este, en la emergencia del tema del «dolore». «Sciacquio d'ogni gesto» (v. 2), «Ogni gesto percuote la calma d'allora» (v. 12), «Se suonasse la voce [...] tornerebbero i gesti» (v. 14), «i gesti del vano dolore» (v. 18).

Un elemento espacial completa este focalizador de la temporalidad repetitiva, en el que podrán emerger los tres grandes temas del poema: «silenzio», «voce» y «dolore»; se trata del contrapunto del «aria»: «si chiude [...] come l'aria» (vs. 2 y 3), «l'aria immobile» (v.7), «nell'aria stupita» (v. 14).

b. Cuando el destrenzado semántico y musical de estos elementos se agota, justo a la mitad del poema, estos temas o motivos son sustituidos por otros, con una función musical muy similar, pero con una función semántica muy distinta, pues son los encargados de acompañar la melodía principal hacia el final del poema.

En primer lugar, un elemento verbal que instala el poema, de nuevo en la experiencia, en este caso imposible, de la temporalidad; me refiero al uso ya estudiado de los tiempos verbales propios de la ausencia y de la inacción; el modo potencial de la probabilidad hipotética, regidos, en sus cuatro apariciones, por un verbo en modo condicional: «se suonnasse la voce» (v. 13 y v. 16), «tornerebbe il dolore» (v. 13), «tornerebbero i gesti» (v.14), «se farebbe il dolore (v. 17), para desembocar en la totalidad semántica del verso 18 que inicia el final del poema: «Tornerebbero i gesti del vano dolore, percuotendo...»; (pero de este final hablaremos dentro de unas líneas). Con esta repetición, centrada en el verbo tornare (el verbo por antonomasia de la repetición musical) se crea una dislocación brutal en el poema, pues todo lo circunstancial puede volver, frente a la imposibilidad de la vuelta de lo esencial, «la voce» que da título y razón de ser al poema.

En segundo lugar, la emergencia brutal y perfectamente situada, a modo de falsa rima (repetición de la misma palabra - dolore / dolore -, eco sonoro imperfecto de dos palabras que sí contienen elementos sonoros análogo, pero sin llegar a constituir una rima, aunque no se puedan reducir a simple aliteración - allora, dolore -, síntesis final de todos estos elementos sonoros, - or, do, ore, ora, alo, olo - en el binomio final - «ricordo d'allora»), la emergencia, digo, de la alternancia entre «calma d'allora» (versos 11 y 12) y «dolore» (versos 17 y 18), que se resuelve en el verso final del poema, «nel ricordo d'allora» (v. 23): «ricordo», como experiencia de la temporalidad ya vivida; «allora», como abolición de sí misma.

c. En medio de este acompañamiento, como repartido en dos tonalidades distintas, la primera menor y la segunda mayor, se van entrelazando, ahora a lo largo todo el poema, aunque con cierto retraso en la aparición de uno de ellos, tres motivos, similares a esas melodías schubertianas subalternas, como distantes de la melodía principal a la que acompañan - schubertianas, tal es la delicadeza doliente que enrosca, golpea y oprime sus zarcillos.

Primero, la melodía del silencio, casi con resonancia de acompañamiento aún- a modo de bajo continuo: «silenzio della camera sola» (v.1), «La voce [...] non torna nel fresco silenzio» (v. 5), «La voce [...] no rompe il silenzio» (v. 8), «il palpito breve / del silenzio che dura» (v.17), «per sempre il silenzio tace rauco e sommesso» (v. 23). Asumiendo, finalmente, il silenzio (ya lo vimos y volveremos sobre el tema) los elementos adjetivales de la voce: un silencio rauco y sommesso. 
En segundo lugar, como eje temático y musical de todo el poema, La voce: «la voce / rauca e dolce non torna» (vs. 4 y 5), «la voce è la stessa [...] rauca e uguale» (v. 8), «se suonasse la voce (v. 13), «ah la voce sommessa» (v. 15), «se suonasse la voce» (v. 16), «ma la voce non torna» (v. 20). Observemos cómo queda enmarcado el tema de «la voce» por dos verbos esenciales, como decíamos, en esa experiencia de la temporalidad abolida: «la voce [...] non torna» y «Ma la voce non torna».

Esta imposibilidad de volver y la sospecha de que pudiera volver se contraponen, creando la evolución del tema y haciendo posible la aparición del tercer tema musical, que nace, como decía con anterioridad, con cierto retraso (justificado), al final de la segunda estrofa, pero con la finalidad de concluir semántica y musicalmente el poema: se trata del tema de «il ricordo»: «nell'immobilitá del ricordo» (v. 10), «Ma la voce [...] / non increspa il ricordo» (v. vs. 20, 21), «nel ricordo d'allora» (v. 23).

Ahora bien, como casi siempre suele ocurrir en el poema, el elemento que lo informa y que arrastra tras sí todos los signos externos de la poeticidad instrumental sólo suele ser el soporte de un elemento más profundo (más conceptual, tal vez, si no más profundo): el nivel que llamo noémico, en mi topología de la estructuración metafórica del poema. Aquí este nivel parece ocupado por el silencio (la ausencia de voz) que reduciendo la voz al recuerdo de voz, aunque arrastrando tras sí las cualidades de ésta (rauca, dolce, fresca y sommessa), permite al yo lírico instalarse en la ausencia dolor - «vano dolore».

La última estrofa (de nuevo surge la esencia musical de la palabra poética) recupera todas las cadenas temáticas que recorren de capo a coda la totalidad del poema, ofreciéndonos un impresionante finale: gesto, voce, silenzo, ricordo, dolore - passando del ogni giorno de la temporalidad cotidiana al allora de la temporalidad mitificada en un pasado indeterminado.

\section{Il carrettiere}

Se puede argumentar, tomando en consideración el análisis que precede, que este está basado en elementos que pertenecen a un poema que podríamos incluir, sin ninguna dificultad, en el apartado de las pervivencias simbolistas decadentes, más o menos diseminadas, más o menos concentradas, por las páginas de Lavorare stanca. Como contrapunto poético, plenamente ligado al poema-racconto procedo al análisis "musical" de Il carrettiere: poema que, como ya hemos visto, tiene elementos anecdóticos suficientes como para haber generado una clara organización narrativa del texto.

Aquí el primer verso (y por ampliación la primera estrofa), a modo de introducción, a modo de obertura anunciadora, condensa de golpe cuantos temas van a desfilar por el horizonte multiplicado de la partitura: «Lo stridore del carro scuote la strada...»: lo stridore, il carro, el verbo scuoter y la strada -una simple frase, con su sujeto, su verbo y su predicado; temas, estos, y musicalidad completados por los elementos circunstanciales (alba, buio, cielo) y por la condición de disteso, en la que está sumido aquel que aún duerme (carretero o sujeto lírico) y por «la lanterna che 
dondola»- elementos, ambos, que se convertirán en esenciales al final del poema. Veamos ya, desde este inicio, un claro enfrentamiento entre la rudeza musical y temática del tema principal y la suavidad del tema secundario que le sirve de contrapunto o de acompañamiento ambiental (real y psicológico). Pero analicemos más en detalle cada uno de sus componentes.

a. Lo stridore crea su propia cadena sonora y temática -«stridore del carro» (v. 1), «stridore più roco» (v. 13), siendo, en este caso, la cadena sonora la más importante; primero de manera, digamos, directa, mediante la creación de una rima interior que recorre todo el poema: stridore, tepore, calore, stridore, calore (versos 1, 6, $11,13,17)$; luego, de manera indirecta, al proyectar su sonoridad, articulada en torno a dos eres, sobre su complemento de nombre inmediato, carro, sobre las modulaciones adjetivales de este (roco) y sobre el contenido simbólico de este carro, un ricordo- pero veremos a su debido tiempo las cadenas que ambas palabras generan. Ahora me basta poner de manifiesto el poder germinativo de «stridore del carro», como tonalidad que invade la totalidad de poema: un poema en ere mayor, podríamos decir.

b. En ausencia textual del carrettiere, el carro asume todo el protagonismo del poema racconto. Aquí, sí podemos decir (ya lo hemos dicho) que estamos ante un poema de acción -la del «carro che va»: «va col carro un tepore» (v. 6), «va col carro nel sonno un ricordo» (v.9), «lo stridore più roco del carro che va» (v. 13) $)^{47}$, verso que completa los resortes sonoros del poema al insistir por tres veces en la consonante que acompaña a la ere: la $k$ de roco, carro y che-yendo, hacia el principio y hacia el final del poema, al encuentro de scuote (el verbo esencial de la estructura temática del poema, tanto en su nivel naturalista como en su nivel simbólico) y de los dos soportes semánticos de dicha estructura: la naturalista, los sacchi, hermanados a la simbólica, los ricordi ${ }^{48}$.

Es esencial la segunda presencia de carro en el verso 4 del poema: «sotto il carro s'è spenta [...] / la lanterna» (vs. 4 y 5). Esta presencia, naturalista, permite la evolución semántica del poema, dándole cobijo material a un elemento espiritual como es el recuerdo que «s'affonda nell'ombra di ieri / dove balza il camino e la fiamma viva» (vv. 24 y 25 ).

c. El verbo scuotere (sacudir, agitar) aparece tres veces, una al principio y dos al final del poema, pero esta triple aparición es de una importancia capital; materializa, en un primer nivel, el ritmo constante pero sincopado del carro por el camino, desde el momento en el que la linterna dondola (se balancea), hasta el momento en el que la llama viva de la chimenea -y en ellos el recuerdo-balza (brinca), con un ritmo sincopado, análogo al ritmo del poema. Pero este verbo también aparece cuando el poema pasa de manera definitiva del nivel naturalista al nivel simbólico, trans-

47 Verso de una rotundidad absoluta, sin abandonar un ápice el deseado naturalismo esencial.

48 No conviene olvidar otros elementos esenciales que redundan en esta melodía que tiene a la $\mathrm{R}$ como dominante y a la K como elemento segundo de la modulación sonora: «parole arrochite» (v. 12), «voci roche» (v. 18), «quegli occhi» y «con gli occhi» (vv. 20 y 22, respectivamente). 
firiéndose de los ojos «che scuotono il sangue» (v. 20) a «i sacchi [che] scuotono / chi è disteso e li preme» (v. vs. 21 y 22), con los ojos orientados hacia el cielo, en un proceso brutal de interiorización.

d. Emerge en la segunda estrofa il ricordo - «va col carro nel sonno un ricordo già desto...»- (v. 9), como si este fuera la auténtica carga del carro: «il ricordo di ieri» (v. 16), el «ricordo [che] si stringe ai sacchi» (v. 24) y, finalmente, «il ricordo [che] s'affonda nell'ombra di ieri».

El trasvase semántico se ha consumado; y vemos cómo el poema se articula en torno a una bisagra imaginaria que reparte la materia en dos mitades irregulares (una exterior y otra interior), cuya percepción acentúan parejas de términos aparentemente circunstanciales, colocados como de manera especular, al principio y al final del poema: «sotto l'alba» (v. 2) y «all'alba» (v. 10); «il cielo» (v. 4) y «al cielo» (v. 22); «che sa d'osteria» (v. 6) y «[sarà] l'osteria» (v. 18); «ricordo di ieri» (v. 16) y «ombra di ieri» (v. 24).

\section{Siempre queda la duda}

¿Es a este proceso de escritura (tan discreto en cuanto a los procedimientos retóricos que emplea, no así en cuanto a los procedimientos musicales) al que podemos llamar visión esencial y dicción esencial de la realidad, tal como Pavese la busca? Mi experiencia de historiador y de teórico de la poesía (sin abandonar la conciencia dubitativa que me es propia a la hora de afirmar cualquier conclusión de alcance estético) me lleva a decir que sí. Incluso más: y me arriesgo a decir que, imposible ya una poesía capaz de asentarse en cualquier tipo de trascendencia real, inútil ya una poesía que sólo pretendiera crear belleza en la plasticidad del verso, obscena ya una poesía que se obcecara en hozar por las interioridades de un yo archisabido desde la ciencia y desde la psicología (a no ser que se sueñe, imbécil, una singularidad ontológica intransferible), cargante aún una poesía del lamento ante los dolores $^{49}$ inconmensurables que puede alojar un corazón burgués, la única poesía digna que le queda al poeta moderno es aquella capaz de ver y decir la realidad en sus situaciones y en sus relaciones inéditas, reales pero insólitas - una actitud y una actividad análogas de las que pasea el fotógrafo (que se siente creador de otra realidad) por los seres y las cosas.

49 Pero tampoco es de buen tono recrearse en la alegría o en la belleza, a las que el yo moderno sigue teniendo acceso, salvo en depresiones y cinismos. 


\section{ANEXO I}

\section{La voce}

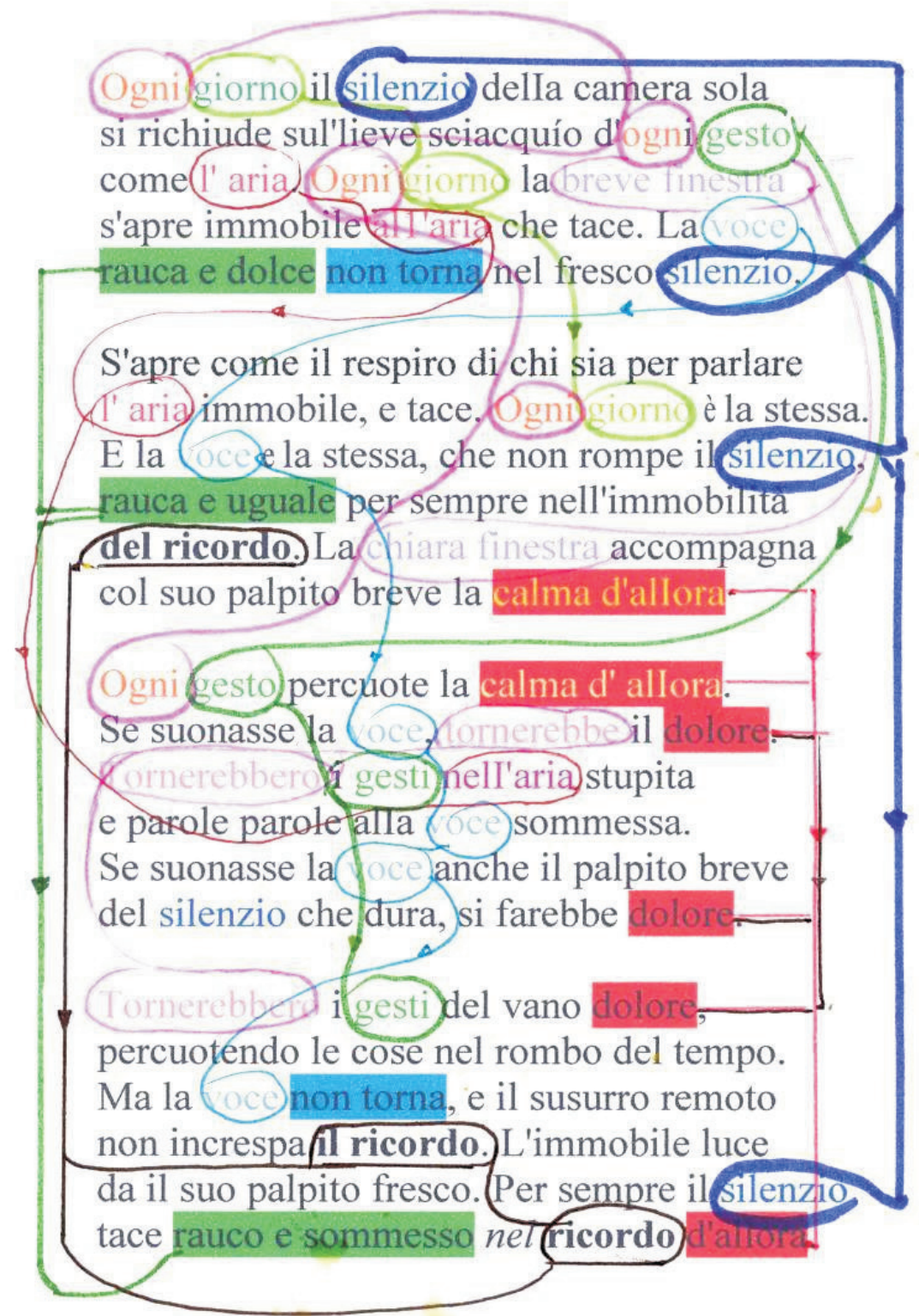




\section{ANEXO II}

\section{Il carrettiere}

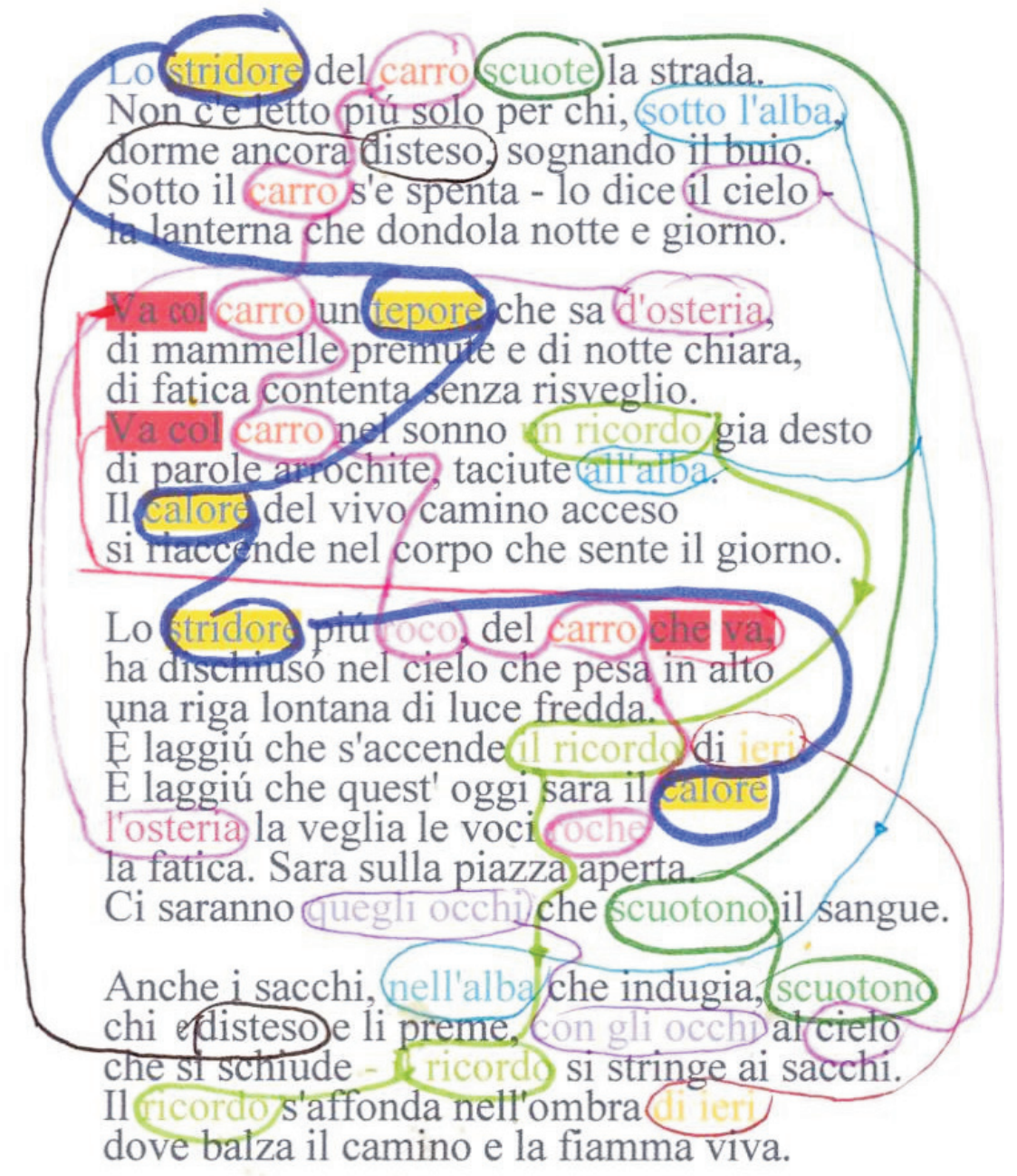




\section{Bibliografía}

Allan PoE, Edgar (2002): La filosofía de la composición, ed. bilingüe a cargo de José Luis Palomares. Madrid, Ediciones Langre.

ANSÓN, Antonio, PRADO, Javier del y otros (2006): Cómo leer un poema. Estudios interdisciplinares. Zaragoza, Prensas Universitarias de Zaragoza.

BARTHES, Roland (1953): Le degré zéro de l'écriture. Paris, Seuil.

BonNEFOY, Yves (1977): «À l'horizon de Morandi», en Le nuage rouge. Paris, Mercure de France.

Cabral de Melo, Joao (1999): Poesía y composición. Méjico, Universidad Iberoamericana.

Delas, Daniel, y TERrY, Marie-Louise (ed) (1991): Rythme et écriture 2. Paris, Université de Paris X.

DOLCE, Edoardo (1968): «Il problema dell'unità poetica in Cesare Pavese», Rivista di estetica, XIII, 2, pp. 252-289.

Claudel, Paul (1963): Réflexions sur la poésie. Paris, NRF, coll. « Idées ».

EliOT, Thomas S. (2004): El bosque sagrado, ed. de José Luis Palomares. Madrid, Ediciones Langre.

ELITIS, Odiseas (1988): El dedo trascendente, «introducción» al Catálogo, Elitis, un mediterráneo universal. Paris, Centro Pompidou.

Glaize, Jean Marie (1995): La poésie. Textes critiques. XIV-XX siècle. Paris, Larousse.

HeIDEgGER, Martin (1998): Caminos del bosque. Madrid, Alianza Editorial.

LINSKY, Leonard (1974): Le problème du référent. Paris, Seuil.

PAVESE, Cesare (1998): Le poesie a cura di Mariarosa Masoero, con introducción de M. Guglielminetti. Torino, Einaudi.

PAVESE, Cesare (1980): El oficio de vivir y El oficio de poeta. Barcelona, Bruguera-Alfaguara.

PAVESE, Cesare (2006): Dialoghi con Leucò, a cura di Sergio Givone. Torino, Einaudi.

PÉREZ ZENTENO, Martín (coord.) (1980): El poeta y su trabajo. Méjico, Editorial Universidad Autónoma de Puebla.

PessoA, Fernando (1985): Sobre literatura y arte. Madrid, Alianza Tres.

PRADO, Javier del (1983) : Cómo se analiza una novela. Madrid, Alhambra.

PRADO, Javier del (1993): Teoría y práctica de la función poética. Madrid, Cátedra.

PRADO, Javier del (1995): «Beaumarchais y el complejo de Mentor», in Homenatge a Victor Siurana. Lleida, Ajuntament de Lleida, pp. 245-253.

PRADO, Javier del (2006): "De las formas fijas a las formas abiertas: un falso problema de la poesía», en A. Ansón, del Prado y otros, Zaragoza, Prensas Universitarias de Zaragoza, pp.: 6-60.

RABATÉ, Dominique (ed.) (1996): Figures du sujet lyrique. Paris, PUF.

STRAVINSKY, Igor (2000): Poétique musicale. Paris, Flammarion. 